\title{
Halotolerant Endophytic Bacterium Serratia rubidaea ED1 Enhances Phosphate Solubilization and Promotes Seed Germination
}

\author{
Ismail Mahdi ${ }^{1,2}$ (D), Mohamed Hafidi ${ }^{2,3}$, Abdelmounaaim Allaoui ${ }^{4}$ and Latefa Biskri ${ }^{4,5, *(D)}$ \\ 1 Medical Applications Interface Center (CIAM), Mohammed VI Polytechnic University (UM6P), \\ Ben Guerir 43150, Morocco; ismail.mahdi@um6p.ma \\ 2 Laboratory of Microbial Biotechnologies, Agrosciences and Environment, Faculty of Sciences Semlalia, \\ Cadi Ayyad University, Marrakesh 40000, Morocco; hafidi@uca.ac.ma \\ 3 AgrobioSciences Department, Mohammed VI Polytechnic University (UM6P), Ben Guerir 43150, Morocco \\ 4 Laboratory of Molecular Microbiology, Coalition Center, for Innovation, and Prevention of Epidemics \\ in Morocco (CIPEM), Mohammed VI Polytechnic University (UM6P), Ben Guerir 43150, Morocco; \\ abdelmounaaim.allaoui@um6p.ma \\ 5 African Genome Center (AGC), Mohammed VI Polytechnic University (UM6P), Ben Guerir 43150, Morocco \\ * Correspondence: latefa.biskri@um6p.ma; Tel.: +212-52502926
}

Citation: Mahdi, I.; Hafidi, M.; Allaoui, A.; Biskri, L. Halotolerant Endophytic Bacterium Serratia rubidaea ED1 Enhances Phosphate Solubilization and Promotes Seed Germination. Agriculture 2021, 11, 224. https://doi.org/10.3390/ agriculture11030224

Academic Editor: Cristina Abbate

Received: 4 February 2021

Accepted: 27 February 2021

Published: 9 March 2021

Publisher's Note: MDPI stays neutral with regard to jurisdictional claims in published maps and institutional affiliations.

Copyright: (c) 2021 by the authors. Licensee MDPI, Basel, Switzerland. This article is an open access article distributed under the terms and conditions of the Creative Commons Attribution (CC BY) license (https:// creativecommons.org/licenses/by/ $4.0 /)$.

\begin{abstract}
Quinoa is renowned for its nutritional value and ability to withstand harsh environmental conditions such as salinity. In the present work, we isolated 34 phosphate solubilizing endophytic bacteria associated with the roots of quinoa plants. Based on phosphate solubilization efficiency and biochemical characterization, we selected one isolate named ED1. Ribotyping using partial 16S RNA gene analysis revealed that the selected isolate shares $99.7 \%$ identity with Serratia rubidaea. Plant growth promoting (PGP) studies showed that the ED1 strain solubilized complexed forms of phosphate $\left(\mathrm{Ca}_{3}\left(\mathrm{PO}_{4}\right)_{2}\right)$. Zinc release from $\mathrm{ZnO}, \mathrm{Zn}_{3}\left(\mathrm{PO}_{4}\right)_{2}$, or $\mathrm{ZnCO}_{3}$ revealed the efficient $\mathrm{ZnO}$ solubilization by the ED1 strain. Except for proteases, the strain ED1 produced siderophores, cellulase, ammonia and exhibited oligonitrophilic features. Indole acetic acid (IAA) production was detected with and without the L-tryptophan precursor. Next, we demonstrated that the ED1 strain tolerated $1.5 \mathrm{M} \mathrm{NaCl}$ final concentration and exhibited intrinsic resistance to seven antibiotics frequently prescribed for medical use. Moreover, we found that ED1 strain withstood $2 \mathrm{mg} / \mathrm{L}$ of Cadmium and $1 \mathrm{mg} / \mathrm{L}$ of either Nickel or Copper. Furthermore, we observed that $S$. rubidaea ED1 stimulated quinoa seeds germination and seedlings growth under salt stress conditions. Lastly, we discuss the advantages versus disadvantages of applying the S. rubidaea ED1 strain as a beneficial agent for salty and/or heavy metals contaminated soils.
\end{abstract}

Keywords: endophyte; Chenopodium quinoa willd.; Serratia rubidaea; plant growth promotion; salt stress; antibiotics resistance; heavy metals tolerance

\section{Introduction}

Plant associated endophytic microorganisms are considered as the second functional genome of host plants [1]. In 1995, endophytes were defined as symbiotic microorganisms (bacteria, archaea, fungi, and protists) residing within the plant endosphere without causing any detrimental impact to the host plant [2]. Hardoim et al. (2015) stated that any colonizing microbe of plant tissues could be classified as endophyte regardless of the outcome of its association with the host plant [3]. However, colonization by endophytes is crucial for providing benefits to plants [4]. Indeed, the interaction of endophytes with plants is characterized as a symbiotic relationship because of mutual benefits. The plant provides protective niches to the internal microorganisms which, in turn, act directly by promoting plant growth through nitrogen (N) fixation, phytohormone, and metabolites production, and indirectly by stimulating availability and absorption of macro and micronutrients and 
water. In addition, endophytic microorganisms induce host tolerance to abiotic stresses such as osmotic stress, exposure to heavy metals and xenobiotic molecules, and assist in the biocontrol of plant pathogens $[5,6]$.

Plant growth promoting microorganisms (PGPM), including endophytes, have an immense potential to boost plants' performance and to reduce the environmental impacts caused by chemical inputs as increasing agricultural productivity is of the upmost priority around the globe [4,7]. Indeed, bacterial endophytes have been reported to prime plants for faster and more intense defense responses upon pathogen attacks at low physiological cost to the plant [8]. Endophytes also stimulate seedlings' emergence and enhance plant growth under adverse conditions $[9,10]$. Inoculation of plant growth promoting endophytic (PGPE) bacteria in plants has low environmental impact, requires low-cost techniques, and could be of immense economic importance.

Plants are complex micro-ecosystems where the different tissue and surface compartments are exploited by a wide variety of microorganisms [11]. PGPE bacteria have been isolated from several plants such as wheat roots [12], sweet potato roots [13], rice roots [14], sugarcane stems [15], bean leaves [16], and quinoa seeds [17]. Plants interact with microbes primarily at the roots. Despite the crucial role of root bacterial communities in plant health and nutrient assimilation, the current understanding of the complex plant-microbe interactions is still in its infancy. At the soil-root interface, roots provide different microhabitats: rhizospheric soil, rhizoplane, and endorhizosphere [18].

Among phytohormones, auxins (e.g., indole acetic acid (IAA)) are the main plant growth regulators having many physiological actions including elongation of primary roots, differentiation of tissues, formation of pigments, stimulation of nitrogen fixation, and resistance to various stresses. Plants associated microorganisms can synthesize IAA via tryptophan-dependent pathways by converting tryptophan to different intermediates. This pathway of IAA biosynthesis has been demonstrated in the majority of soil bacteria [19]. However, some microorganisms are endowed with the ability to produce it via tryptophanindependent routes [20].

Salinity in one of the most devastating stresses in agriculture, especially in arid and semiarid environmental areas [21]. It considerably reduces plant growth and productivity because of nutritional imbalance in plants (increase in $\mathrm{Na}^{+}$and decrease in $\mathrm{K}^{+}$uptake), inhibition of protein synthesis, enzyme inactivation, early senescence, decrease in photosynthesis and respiration, and loss of cellular integrity $[22,23]$. Nowadays, methods to increase tolerance of plants to salinity involve the use of salt tolerant crops, transgenic plant genetic engineering, and traditional breeding [24]. Unfortunately, these strategies are labor-intensive and highly technical [25]. The alternative strategy to sustain plant growth under salty conditions is the use of PGPB (plant growth promoting bacteria). These latter can be found both at the root surface and in endophytic associations with host plant. These bacteria can either directly or indirectly enhance plant growth in normal and stressful conditions [25-27]. Several bacterial species have been reported to mitigate salinity stress and stimulate plant growth. They include Klebsiella sp., Burkholderia sp., Enterobacter sp. [23], Microbacterium sp., Alcaligenes sp. [28], Ochrobactrum sp. [28], Bacillus sp. [23,29], Arthrobacter sp. [30], Pseudomonas sp. [31], Bacillus licheniformis and Enterobacter asburiae [32], and finally Serratia sp. [33].

Several studies have tackled the emergence and propagation of antibiotic resistance (ARG) genes in different environmental reservoirs through different anthropogenic activities such as the application of manure, slurry, and soil amendments with regard to their different transfer pathways and threats to public health and ecology [34]. However, ARG-harboring PGPB inoculants are mostly unexplored, while most of these PGPB are still recommended as potential effective biofertilizers. Despite the importance of antibiotic resistance in helping biofertilizers-based bacteria to survive and compete the respective native microflora in open microbial habitats [35], large-scale application of ARG-harboring biofertilizers into the soil can rise new resistances and worsen the spread of ARG in other ecosystems.

Quinoa (Chenopodium quinoa Willd.), an herbaceous plant species belonging to the amaranthaceae family [36], is one of the most promising crops for tomorrow's food demand 
and nutritional security. Originally from South America, quinoa was heavily cultivated by the ancient Andean civilization, but it was not until the 1970s that quinoa began to be introduced all over the world. Quinoa is renowned for its ability to withstand harsh environmental conditions such as drought, salinity, wind, and heat $[37,38]$ and its outstanding nutritional value [39] with high content of vitamins, and good quality of proteins and saponins [40]. Quinoa crop has recently gained attention and its cultivation is spreading worldwide. In the developing countries of Africa and Asia, quinoa represents a miracle solution to provide highly nutritious food [41] due to its growth adaptability to various environmental conditions. In Morocco, it has started to be cultivated for its income-generating potential, its adaptability to different soil and climatic conditions, and its potential to improve cropping systems [42]. More importantly, it grows up to an altitude of $4000 \mathrm{~m}$ above sea level, resists a wide daily temperature ranges, needs only $300 \mathrm{~mm}$ of precipitation per year, and is produced in a short period of time [40]. Given the ability of halophyte quinoa plants to cope with abiotic stresses and extreme environments, we hypothesized that quinoa-associated endophytic bacteria may be involved in the acquisition of such tolerance as well as in promoting plant growth. Herein, we identified a phosphate solubilizing endophytic bacterium inhabiting the roots of quinoa plants cultivated in Morocco and characterize its PGP properties in vitro. We also assessed its ability to withstand extreme conditions such salt and heavy metals stresses.

\section{Materials and Methods}

\subsection{Plant Material and Sampling}

Root samples were collected from Chenopodium quinoa plants growing in different locations at the experimental farm (32.219731 E, -7.892268 N) of Mohammed VI Polytechnic University, Ben Guerir, Morocco. Sampling was carried out in June 2018, peak growing season for quinoa. Six plants were randomly selected for root sampling, and roots without visible damage were collected under aseptic conditions and transported to the laboratory for further analysis.

\subsection{Isolation of Root-Borne Bacterial Endophytes}

Primary and secondary roots were washed under running tap water to remove soil debris, then surface-sterilized with ethanol (70\%) for $3 \mathrm{~min}$ and sodium hypochlorite $(3 \%)$ for $1 \mathrm{~min}$, followed by three rinses in sterile distilled water for 3 min each [43,44]. To ensure the success of surface sterilization treatments, the last water wash solutions as well as sterilized roots were respectively deposited on TSA (Trypticase Soy Agar, BIOKAR Diagnostics, BEAUVAIS, France) plates and cultivated overnight [44]. The sterilized root pieces were ground in $0.85 \%$ aqueous $\mathrm{NaCl}$ using a mortar and pestle. Next, serial dilutions $\left(10^{-1}\right.$ to $\left.10^{-5}\right)$ were generated, and each dilution was spread on a TSA medium using a glass spreader [16]. Plates were then incubated at $30^{\circ} \mathrm{C}$ for $24 \mathrm{~h}$. Emerging colonies were subcultured to obtain pure isolates.

\subsection{Plate Assay for Phosphate Solubilizing Activity}

The purified bacterial isolates were subjected to phosphate solubilization activity screening. Using nitrocellulose membranes, a total of 34 endophytic bacterial colonies grown on TSA plates were transferred to NBRIP (National Botanical Research Institute's phosphate) agar medium plate [45] consisting of $(\mathrm{g} / \mathrm{L})$ dextrose 10; hydroxyapatite 5 (purum p.a., $\geq 90 \%$ (as $\left.\mathrm{Ca}^{3}(\mathrm{PO} 4)_{2}, \mathrm{KT}\right)$; ammonium sulphate 0.5 ; potassium chloride 0.2 ; sodium chloride 0.2; magnesium sulphate 0.1 ; ferrous sulphate trace; manganese sulphate trace; agar 15; and the $\mathrm{pH}$ was adjusted to $6.75 \pm 0.25$ before autoclaving [46]. Plates were incubated at $30^{\circ} \mathrm{C}$ and checked daily for 7 days for the appearance of transparent halos indicating P-solubilizing ability. Based on the growth on selective medium and discrete halo zones appearance, one selected isolate (named ED1) was subcultured several times, purified on the same medium, then stored at $-80{ }^{\circ} \mathrm{C}$ in cryotubes using $10 \%$ dimethyl sulfoxide (DMSO) as a cryoprotective agent. 


\subsection{Ribotyping Identification of Isolated Strains}

The polymerase chain reaction (PCR) was performed on bacterial 16S rRNA gene using primers: forward pA (5'-AGAGTTTGATCCTGGCTCAG-3') and reverse 926R (5'CCGYCAATTYMTTTRAGTTT- $3^{\prime}$ ) [47] generating an amplicon of $910 \mathrm{bp}$. The PCR reaction mixture contained $23 \mu \mathrm{L}$ DNAase free water, $1 \mu \mathrm{L}$ of forward and reverse primers at $20 \mu \mathrm{M}$ final concentration, $25 \mu \mathrm{L}$ PCR SuperMix (Invitrogen, Carlsbad, CA, USA), and $1 \mu \mathrm{L}$ of fresh bacterial cultures as a DNA matrix. The amplification process was launched according to the following program: initial denaturation step for $5 \mathrm{~min}$ at $94{ }^{\circ} \mathrm{C}$, denaturation for $1 \mathrm{~min}$ at $94{ }^{\circ} \mathrm{C}$, hybridization for $1 \mathrm{~min}$ at $52{ }^{\circ} \mathrm{C}$, elongation step for $1 \mathrm{~min} 30 \mathrm{~s}$ at $72{ }^{\circ} \mathrm{C}$ with 35 cycles, and finally an incubation for $10 \mathrm{~min}$ at $72{ }^{\circ} \mathrm{C}$. Then, $5 \mu \mathrm{L}$ of each PCR sample was checked on agarose gel. The amplicons were sequenced and generated nucleotide sequences were aligned using the ExPASy Bioinformatics Resource Portal (https:/ / www.expasy.org/ (accessed on 20 November 2020)), and compared to available homologous sequences using the BLAST search (Basic Local Alignment Search Tools, NCBI (https:/ /blast.ncbi.nlm.nih.gov/Blast.cgi (accessed on 20 November 2020))) and the High-Quality Ribosomal RNA database (SILVA (https: / / www.arb-silva.de/ (accessed on 20 November 2020)) [48]. The phylogenetic dendrogram was generated by the NeighborJoining method using Unipro UGENE software, version 1.32.0 [49].

\subsection{In Vitro Assessment of PGP Attributes and Extreme Growth Properties}

\subsubsection{Heat, Salt, and $\mathrm{pH}$ Tolerance}

To assess for heat tolerance, bacteria were streaked on TSA plates and further incubated for $24 \mathrm{~h}$ at various temperatures: $20,25,30,37,42,45$, and $50{ }^{\circ} \mathrm{C}$ [50]. Salt tolerance was firstly evaluated on a TSA medium by supplementing plates with various concentrations of $\mathrm{NaCl}(0$ to $14 \%)(w / v)$ and incubated at $30{ }^{\circ} \mathrm{C}$ for $48 \mathrm{~h} \mathrm{[51].} \mathrm{The} \mathrm{salt} \mathrm{and} \mathrm{heat}$ tolerance of the isolate was confirmed by observing its growth on salt-supplemented and nutrient agar media. B. licheniformis QA1 [32] and Esherichia coli DH5 $\alpha$ were used as positive $(\mathrm{C}+)$ and negative $(\mathrm{C}-)$ controls, respectively. To determine the optimum salinity tolerance of the selected bacterium, we used 48-well microtiter microplates; each well was filled with $500 \mu \mathrm{L}$ of TSB broth supplemented with various $\mathrm{NaCl}$ concentrations $(0,2,4,6,8$, $10,12,14$, and $16 \%)(w / v)$. In addition, $\mathrm{pH}$ tolerance was assessed by adjusting the $\mathrm{pH}$ of the media at different levels $(2,3,4,5,6,7,8,9,10,11$, and 12). Five microliters of an overnight bacterial culture $\left(\mathrm{OD}_{600 \mathrm{~nm}}=0.8\right)$ was inoculated in each well and incubated at $30^{\circ} \mathrm{C}$ under shaking at $150 \mathrm{rpm}$. Growth was measured after $24 \mathrm{~h}$ by colorimetry at $\mathrm{OD}_{600 \mathrm{~nm}}$ using the VICTOR NivoTM Multimode Plate Reader (Perkin Elmer, Casablanca, Morocco) [52].

\subsubsection{Phosphate Solubilization Assay under Salt Stress Conditions}

Inorganic phosphate solubilization by bacteria was studied in a liquid medium. Bacterial suspension of $\mathrm{OD}_{600 \mathrm{~nm}}=0.8$ was inoculated into $50 \mathrm{~mL}$ of NBRIP broth containing $0 \%, 4 \%$, and $8 \% \mathrm{NaCl}$ concentrations and incubated in an incubator shaker at $30{ }^{\circ} \mathrm{C} / 150 \mathrm{rpm}$ [51]. Solubilization of hydroxyapatite (purum p.a., $\geq 90 \%\left(\right.$ as $\mathrm{Ca}_{3}\left(\mathrm{PO}_{4}\right)_{2}$, $\mathrm{KT}$ ) was measured after 5- and 10-days post incubation (DAI; day after incubation). The bacterial broth was centrifuged at $5000 \mathrm{rpm}$ for $10 \mathrm{~min}$, filtered using $0.22 \mu \mathrm{m}$ sterile syringe filters, and $5 \mathrm{~mL}$ of each supernatant was transferred into $50 \mathrm{~mL}$ centrifuge tubes. E. coli $\mathrm{DH} 5 \alpha$ was used as a negative control (C-) [46]. Soluble P concentrations (orthophosphates $\left(\mathrm{PO}_{4}\right)$ ) in each sample were determined using an inductively coupled plasma optical emission spectrometer (ICP-OES) at the Agricultural Innovation and Technology Transfer Center (AITTC) of the Mohammed VI Polytechnic University (UM6P).

\subsubsection{Oligonitrophilic Activity}

To monitor the oligonitrophilic property of the selected bacterium, we used the nitrogen free Jensen's medium [53] containing the following composition (in 1 L): Sucrose $20 \mathrm{~g}$, Dipotassium phosphate $1 \mathrm{~g}$, Magnesium sulphate $0.5 \mathrm{~g}$, Sodium chloride $0.5 \mathrm{~g}$, Ferrous sulphate $0.1 \mathrm{~g}$, Sodium molybdate $0.005 \mathrm{~g}$, Calcium carbonate $2 \mathrm{~g}$, and Agar $15 \mathrm{~g}$. Plates 
were streaked with fresh bacterial culture of isolated bacterium and checked for growth following incubation at $30^{\circ} \mathrm{C}$ for $24 \mathrm{~h}$. B. licheniformis QA1 [32] and E. coli DH5 $\alpha$ were used as positive $(\mathrm{C}+)$ and negative $(\mathrm{C}-)$ controls, respectively.

\subsubsection{Monitoring Indole Acetic Acid (IAA) Production}

To quantify the amounts of IAA produced by the P-solubilizing endophyte, a colorimetric method of Van Urk Salkowski reagent was performed [54]. The isolate was inoculated in LB medium supplemented with $0,0.2$, and $0.5 \%$ of L-tryptophan and incubated at $28 \pm 2{ }^{\circ} \mathrm{C}$ for 11 days under shaking of $150 \mathrm{rpm}$ [55]. The determination of produced IAA was assessed after 3,7 , and 11 days of incubation (DAI). The bacterial cultures were centrifuged at 13,000 rpm for $5 \mathrm{~min}$ at $4{ }^{\circ} \mathrm{C}$. Next, two $\mathrm{mL}$ of Van Urk Salkowski reagent ( $1 \mathrm{~mL}$ of $0.5 \mathrm{M} \mathrm{FeCl}_{3}$ and $50 \mathrm{~mL}$ of $35 \% \mathrm{HClO}_{4}$ ) were mixed with $1 \mathrm{~mL}$ of each supernatant. Mixtures were incubated in the dark for $30 \mathrm{~min}$ [52]. IAA quantification was determined spectrophotometrically at $\mathrm{OD}_{533 \mathrm{~nm}}$ using a standard curve of pure IAA (Sigma Aldrich, Overijse, Belgium) for concentrations in the $0-100 \mu \mathrm{g} / \mathrm{mL}$ range.

\subsubsection{Solubilization of Insoluble Zinc Compounds}

The ability of the selected endophytes to solubilize insoluble $\mathrm{Zn}$ compounds was evaluated on Tris-mineral agar medium [56] containing (in $1 \mathrm{~L}$ ): D-glucose $10 \mathrm{~g}$, $\left(\mathrm{NH}_{4}\right)_{2} \mathrm{SO}_{4}$ $1 \mathrm{~g}, \mathrm{KCl} 0.2 \mathrm{~g}, \mathrm{~K}_{2} \mathrm{HPO}_{4} 0.1 \mathrm{~g}, \mathrm{MgSO}_{4} 2 \mathrm{~g}, \mathrm{pH}=6.75 \pm 0.25$. Prepared media were separately amended with three sources of insoluble $\mathrm{Zn}$ namely zinc oxide $(\mathrm{ZnO}, 15.23 \mathrm{mM})$, zinc phosphate $\left(\mathrm{Zn}_{3}\left(\mathrm{PO}_{4}\right)_{2}, 5.0 \mathrm{mM}\right)$, and zinc carbonate $\left(\mathrm{CO}_{3} \mathrm{Zn}, 5.2 \mathrm{mM}\right)$ at $0.1 \% \mathrm{Zn}$ final concentration [57]. The selected isolate was spot inoculated on each medium and plates were incubated at $30^{\circ} \mathrm{C}$ for 10 days. The appearance of a clear zone around colonies indicate positive $\mathrm{Zn}$ solubilization. B. licheniformis QA1 [32] and E. coli DH5 $\alpha$ were used as positive $(\mathrm{C}+)$ and negative $(\mathrm{C}-)$ controls, respectively.

\subsubsection{Siderophores Production Assay}

The production of siderophores by bacterial isolates was monitored according to the method described by Schwyn and Neilands (1987) [58] using Chromium Azurol S medium

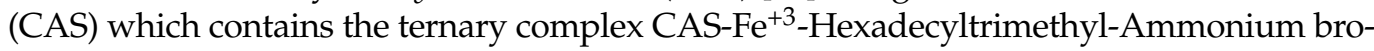
mide as an indicator. The isolate was spot inoculated on CAS plates and incubated at $28 \pm 2{ }^{\circ} \mathrm{C}$ for 5 days. The efficiency to produce siderophores was checked by monitoring the size of the halo zone and the intensity of the color change (blue to yellow or orange). The halo diameter was taken as an indicator of siderophores production intensity. B. licheniformis QA1 [32] and E. coli DH5 $\alpha$ were used as positive $(\mathrm{C}+)$ and negative $(\mathrm{C}-)$ controls, respectively.

\subsubsection{Ammonia Production Assay}

ED1 isolate was tested for ammonia production by adopting the method described by Cappuccino and Sherman (1992) [59]. Fresh bacterial cultures of selected isolate were inoculated into $10 \mathrm{~mL}$ of peptone water and incubated at $28 \pm 2{ }^{\circ} \mathrm{C}$ with shaking at $150 \mathrm{rpm}$. Post $48 \mathrm{~h}$ incubation, $0.5 \mathrm{~mL}$ of Nessler reagent was added to each bacterial culture. A faint yellow color indicated a small amount of ammonia and a deep yellow to brownish color indicated high production of ammonia. The absorbance was measured at $\mathrm{OD}_{450 \mathrm{~nm}}$ and the concentrations of ammonia were estimated using a standard curve of ammonium sulphate $\left(\left(\mathrm{NH}_{4}\right)_{2} \mathrm{SO}_{4}\right)$ for concentrations in $0-0.3 \mu \mathrm{mol} / \mathrm{mL}$ range [60]. B. licheniformis QA1 [32] and E. coli $\mathrm{DH} 5 \alpha$ were used as positive $(\mathrm{C}+)$ and negative $(\mathrm{C}-)$ controls, respectively.

\subsubsection{Cellulase and Protease Production}

To check the production of extracellular cellulase by selected bacterium, we used the mineral-salt agar plates containing $0.4 \%\left(\mathrm{NH}_{4}\right)_{2} \mathrm{SO}_{4}, 0.6 \% \mathrm{NaCl}, 0.1 \% \mathrm{~K}_{2} \mathrm{HPO}_{4}, 0.01 \%$ $\mathrm{MgSO}_{4}, 0.01 \% \mathrm{CaCl}_{2}$ with $0.5 \%$ carboxymethyl cellulose, and $2 \%$ agar, $\mathrm{pH}=6.75 \pm 0.25$. The plates were then spot inoculated and incubated at $30^{\circ} \mathrm{C}$. After 2 days of incubation, a Congo red solution (1\%) was added to the surface of each plate. 20 min later, the plates 
were flooded with a $1 \mathrm{M} \mathrm{NaCl}$ solution and then left to stand for $30 \mathrm{~min}$. The appearance of a clear halo around colonies indicates the degradation of the CMC and reflects the presence of extracellular cellulase [61].

The protease activity was performed according to the method of Kavitha et al. (2013) [62] using the medium having the following composition $\left(\mathrm{g} \mathrm{L}^{-1}\right)$ : Pancreatic casein (5); Yeast extract (2.5); Glucose (1); and Agar (15). The $\mathrm{pH}$ of medium was adjusted to $6.75 \pm 0.25$ and autoclaved. After cooling, $100 \mathrm{~mL}$ of a $10 \%$ skimmed milk solution was aseptically prepared and added to the medium, then seeded by the spot inoculation method. Bacteria with protease activity show a transparent halo around colonies over $48 \mathrm{~h}$ of incubation [63]. B. licheniformis QA1 [32] and E. coli DH5 $\alpha$ were used as positive $(\mathrm{C}+)$ and negative $(\mathrm{C}-)$ controls, respectively.

\subsection{Antibiotic Sensitivity Assay}

Bacterial isolate was tested for its potential resistance to antibiotics on Mueller-Hinton (MH) media (BIOKAR Diagnostics, BEAUVAIS, France) [64] using agar dilution assay, disc diffusion method, and Etest [65]. Freshly prepared MH plates were amended with various concentrations of antibiotics frequently used in the treatment of infectious diseases namely ampicillin $(100 \mu \mathrm{g} / \mathrm{mL})$, kanamycin $(50 \mu \mathrm{g} / \mathrm{mL})$, tetracycline $(10 \mu \mathrm{g} / \mathrm{mL})$, streptomycin $(100 \mu \mathrm{g} / \mathrm{mL})$, chloramphenicol $(20 \mu \mathrm{g} / \mathrm{mL})$, and spectinomycin $(60 \mu \mathrm{g} / \mathrm{mL})$. As for disc diffusion and Etest, $200 \mu \mathrm{L}$ of $18 \mathrm{~h}$ old bacterial culture $\left(\mathrm{OD}_{600 \mathrm{~nm}}=1\right)$ was spread over the entire $\mathrm{MH}$ agar surfaces using a swab stick and left to dry for five minutes before placing the antibiotic-impregnated discs and/or strips. Antibiotic discs of ceftazidime (CAZ; $30 \mu \mathrm{g} /$ disc), ciprofloxacin (CIP; $5 \mu \mathrm{g} /$ disc), meropenem (MRP; $30 \mu \mathrm{g} /$ disc), ertapenem (ETP; $10 \mu \mathrm{g} /$ disc), and vancomycin (VA; $30 \mu \mathrm{g} /$ disc) were placed in triplicate. Etest was adopted using the Liofilchem ${ }^{\circledR}$ Minimum Inhibitory Concentration (MIC) Test Strips with a predefined concentration gradient of imipenem (IMI; $0.002-32 \mu \mathrm{g} / \mathrm{mL}$ ), gentamycin $(\mathrm{CN}$; $0.06-1024 \mu \mathrm{g} / \mathrm{mL}$ ), and cefotaxime (CTX; 0.002-32 $\mu \mathrm{g} / \mathrm{mL}$ ). As a negative control, we used the E. coli DH5 $\alpha$ strain as it is sensitive to all tested antibiotics [66]. In addition, we used a PGPR (Plant Growth Promoting Rhizobacterium) Bacillus atrophaeus strain S8 (MW295957) from our lab collection as an additional control. Resistance patterns were determined following incubation at $30^{\circ} \mathrm{C}$ for $24 \mathrm{~h}$. Positive resistances were considered in antibiotic $\mathrm{MH}$ amended plates by observing the growth of the bacterium on each medium. In disk diffusion plates, the zone of inhibition surrounding discs was measured in millimeters ( $\mathrm{mm}$ ) using calipers near the agar surface [67]. However, the minimum inhibitory concentration (MIC) was read directly from the scale in terms of $\mu \mathrm{g} / \mathrm{mL}$, at the intersection point of the edge of the inhibition ellipse and the MIC Test Strip. Susceptibilities and resistances were analyzed using Zone Size Interpretative Chart (ZSIC) [68,69], Liofilchem $^{\circledR}$ —Antibiotic Disc Interpretative and CLSI Standards for Antimicrobial Susceptibility Testing of Clinical and Laboratory Standards Institute (https:/ / clsi.org/ (accessed on 18 October 2020)).

\subsection{Monitoring Trace Elements Tolerance}

The ED1 isolate was tested for its growth under various concentrations ranging from 0 to $2000 \mu \mathrm{g} / \mathrm{mL}$ of trace metals: $\mathrm{CdSO}_{4}, \mathrm{CuO}_{4} \mathrm{~S} .5 \mathrm{H}_{2} \mathrm{O}$, and $\mathrm{N}_{2} \mathrm{NiO}_{8}$. Stock solutions were prepared in distilled water, sterilized through $0.45 \mu \mathrm{m}$ using sterile syringe filters, and stored at $4{ }^{\circ} \mathrm{C}$. Agar dilution method was followed [70]. Freshly prepared agar plates were amended with increasing soluble heavy metal salts concentrations [71]. The ED1 isolate was streaked in both metal amended and control plates (free metal media). Trace metal tolerance was determined after $48 \mathrm{~h}$ of incubation at $30^{\circ} \mathrm{C}$. B. licheniformis QA1 [32] and E. coli $\mathrm{DH} 5 \alpha$ were used as positive $(\mathrm{C}+)$ and negative $(\mathrm{C}-)$ controls, respectively.

\subsection{Quinoa Seed Germination Assay}

Quinoa seeds of Titicaca variety were used for in vitro seed bacterization to evaluate the early plant growth promoting potential of selected bacterium. Firstly, seeds were sorted and those with damageable aspects were excluded [32]. Seeds were surface sterilized using 
$3 \%$ of sodium hypochlorite for $1 \mathrm{~min}$, soaked in $70 \%$ ethanol for $1 \mathrm{~min}$, rinsed 5 times by sterilized distilled water, and air-dried under a laminar flow hood. The bacterial pellets $\left(\mathrm{OD}_{600 \mathrm{~nm}}=0.8\right)$ were obtained from an overnight bacterial culture by centrifugation at $5000 \mathrm{rpm}$ for $5 \mathrm{~min}$. The pellets were then resuspended in $10 \mathrm{~mL}$ of phosphate-buffered saline (PBS) and used as seed drench [72]. Bacterial suspension was applied as seed drenches for $1 \mathrm{~h}$ with gentle shaking [73]. Afterwards, seeds were air-dried and transferred into $9 \mathrm{~cm}$ sterile Petri dishes on filter paper with a ratio of 30 seeds per plate. Each treatment was performed in triplicate, and seeds treated with PBS were used as negative control [74]. Each filter paper was aseptically wetted with $3 \mathrm{~mL}$ of sterilized distilled saline water solution at $0,200(1.16 \%)$, or $400 \mathrm{mM}(2.32 \%) \mathrm{NaCl}$ [74]. To prevent evaporation and contamination, the plates were closed with parafilm. The plates were labeled and maintained at $25^{\circ} \mathrm{C}$ for $48 \mathrm{~h}$ in the dark [73] and germination rates were monitored $24 \mathrm{~h}$ and $48 \mathrm{~h}$ post-incubation. At the third day, the plates were maintained at room temperature in a day/night cycle $(\sim 12 / 12 \mathrm{~h})$ for an additional $72 \mathrm{~h}$ to compute their morphological traits mainly total length, fresh and dry weight. The germination percentage and vigor index were calculated using the following equations $[74,75]$.

$$
\text { Germination percentage }(\%)=(\mathrm{n} / \mathrm{N}) \times 100
$$

$\mathrm{n}$ : number of germinated seed and $\mathrm{N}$ : total number of seeds.

$$
\text { Vigor index }=\text { Germination percentage }(\%) \times \text { Total seedling length }(\mathrm{cm})
$$

\subsection{Statistical Analysis}

All results obtained were subjected to statistical analysis using IBM SPSS Statistics 20 software. Comparison between means were performed using one-way analysis of variance (ANOVA) followed by the post-hoc analysis with Tukey test. Significant differences were set at $p \leq 0.05$. The results were expressed as the mean of 3 replicates $\pm \mathrm{SD}$. The experiments performed in this study were done in triplicates using a complete randomized design (CRD).

\section{Results}

\subsection{In Vitro PGP Properties of Selected Quinoa Endophytic Bacteria}

3.1.1. $\mathrm{P}$ and $\mathrm{Zn}$ Solubilization, and Oligonitrophilic Activity

A total of 34 isolated endophytic bacteria were screened for mineral phosphate solubilization on NBRIP agar plates. One isolate named ED1 was further selected based on its remarkable capacity to solubilize inorganic $\mathrm{P}$ on plates as evidenced by the halos surrounding colonies (Figure 1). We also checked its ability to solubilize insoluble $\mathrm{Zn}$ from three minerals: $\mathrm{ZnO}, \mathrm{Zn}_{3}(\mathrm{PO} 4)_{2}$, and $\mathrm{CO}_{3} \mathrm{Zn}$. The $\mathrm{ED} 1$ isolate was able to solubilize $\mathrm{ZnO}$ at a greater extend compared to the two other forms, while B. licheniformis QA1 and E. coli DH5 $\alpha$ only solubilized $\mathrm{ZnO}$ (Table 1 ).

In contrast to B. licheniformis QA1 and E. coli $\mathrm{DH} 5 \alpha$ used as positive and negative controls, respectively, the ED1 isolate was able to grow on Jensen's medium which is very poor in nitrogen, indicating its oligonitrophilic activity (Table 1).

Table 1. Summary of relevant plant growth promoting (PGP) traits of the ED1 isolate, the PGPR strain Bacillus licheniformis

\begin{tabular}{|c|c|c|c|c|c|c|c|c|}
\hline \multirow{2}{*}{ Strain/Isolate } & \multirow{2}{*}{$\begin{array}{c}\text { Oligonitrophilic } \\
\text { Activity }\end{array}$} & \multirow{2}{*}{ Siderophore } & \multicolumn{3}{|c|}{ Zinc Solubilization } & \multirow{2}{*}{$\begin{array}{l}\text { Ammonia } \\
(\mu \mathrm{mol} / \mathrm{mL})\end{array}$} & \multicolumn{2}{|c|}{ Extracellular Enzymes } \\
\hline & & & $\mathrm{ZnO}$ & $\mathrm{Zn}_{3}(\mathrm{PO})_{2}$ & $\mathrm{CO}_{3} \mathrm{Zn}$ & & Cellulase & Protease \\
\hline E. coli $\mathrm{DH} 5 \alpha(\mathrm{C}-)$ & - & - & + & - & - & $0.065 \pm 0.048$ & - & - \\
\hline $\begin{array}{l}\text { B. licheniformis } \\
\text { QA1 }(\mathrm{C}+)\end{array}$ & - & +++ & ++ & - & - & $0.48 \pm 0.11$ & ++ & + \\
\hline ED1 isolate & + & + & +++ & + & + & $0.68 \pm 0.04$ & + & - \\
\hline
\end{tabular}
QA1, and E. coli $\mathrm{DH} 5 \alpha(\mathrm{C}-)$.

The values represent means of replicates $(n=3) \pm$ SD. The ' + ' and ' - ' signs indicate efficiencies as follow: - , negative result; + , weakly positive; ++ , moderately positive; +++ , highly positive. Previously published $B$. licheniformis QA1 [32] was used as the PGPR reference strain (C+; positive control) and E. coli $\mathrm{DH} 5 \alpha(\mathrm{C}-$; negative control). 


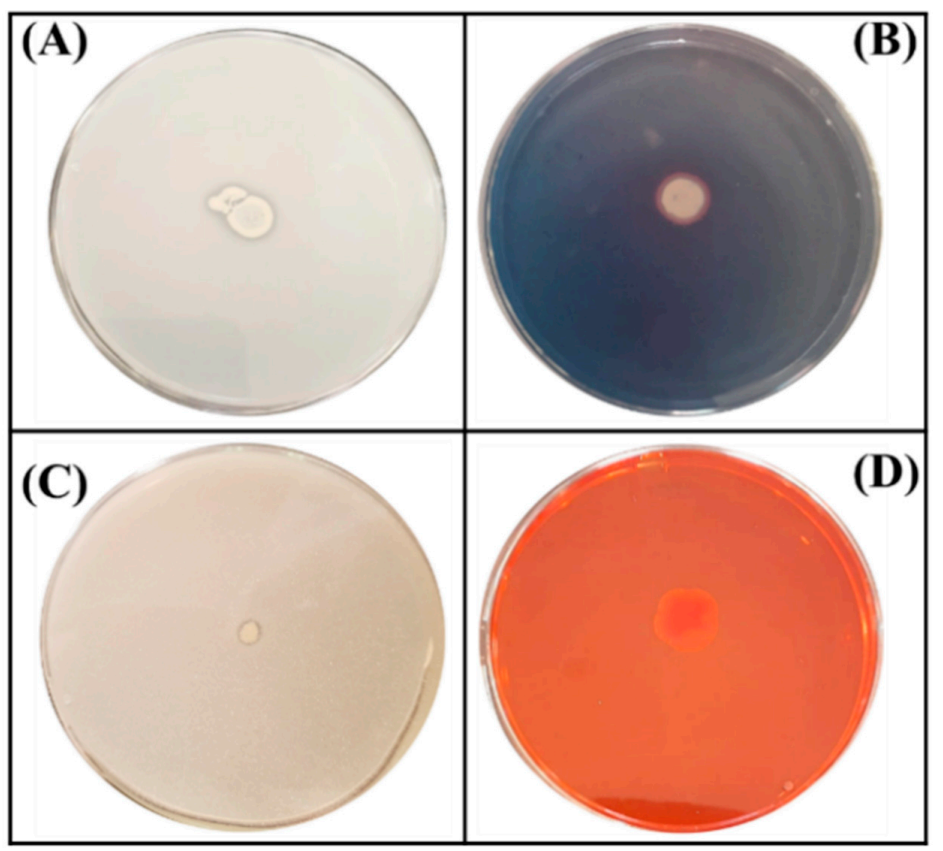

Figure 1. Schematic illustration of four tests performed on plates for the assessment of plant growth promoting traits of the ED1 isolate. (A) Phosphate solubilization, (B) Siderophores production, (C) Zinc oxide solubilization, (D) Cellulase production.

\subsubsection{Siderophores, Ammonia and Extracellular Enzymes Production by the ED1 Isolate}

We next tested the capacity of the ED1 isolate to produce molecules and metabolites of agricultural interest. We showed that it liberated siderophores and produced ammonia and cellulase enzyme (Figure 1). In contrast, no protease activity was detected. In addition, the ED1 isolate was able to grow in peptone water, indicating its capacity to produce ammonia which was 10-fold higher than in E. coli DH5 $\alpha$. Comparatively with the PGPR reference strain B. licheniformis QA1, the selected isolate produced less amounts of siderophores and cellulase but higher concentrations of ammonia (Table 1).

\subsection{The ED1 Isolate Is Related to the Genus of Serratia Rubidaea}

Using the genotyping analysis based on $16 \mathrm{~S}$ rDNA sequencing and sequences comparison to the NCBI and SILVA databases, we found that the ED1 isolate is $99.7 \%$ identical to the genus of Serratia rubidaea. Next, the amplified 16S rDNA sequence was submitted to GenBank and the accession number MW173145 was provided. The phylogenetic tree analysis reflected the same identity with Serratia rubidaea (Figure 2).

\subsection{The Strain S. rubidaea ED1 Tolerates Growth under Stressful Conditions}

We first checker the tolerance of S. rubidaea ED1 to salt. Bacteria were plated on TSA containing various $\mathrm{NaCl}$ concentrations. We found that the ED1 strain grew up to $9 \%$ of $\mathrm{NaCl}$, while the PGPR reference strain, B. licheniformis QA1, tolerated up to $11 \%$. However, the growth arrest happened in E. coli DH5 $\alpha$ at only $3 \%$. In addition, ED1 is a mesophilic bacterium as its optimal growth ranged from 20 to $42{ }^{\circ} \mathrm{C}$ (Table 2). When grown on liquid TSB media with increasing $\mathrm{NaCl}$ concentrations, the maximum growth of the $S$. rubidaea ED1 strain was detected at $4 \% \mathrm{NaCl}$. However, although at reduced growth level, it tolerated up to $10 \% \mathrm{NaCl}$. Total growth inhibition occurred at $12 \% \mathrm{NaCl}$. In contrast to the ED1 strain, the growth of E. coli DH5 $\alpha$ proportionally decreased as the concentration of $\mathrm{NaCl}$ increased (Figure 3A). Next, we monitored bacterial survival at different $\mathrm{pH}$ and found that the optimum growth of both S. rubidaea ED1 strain and E. coli DH5 $\alpha$ occurred at $\mathrm{pH}$ 7. However, S. rubidaea ED1 could still grow in a range of $\mathrm{pH}$ from 4 to 9 (Figure 3B). 


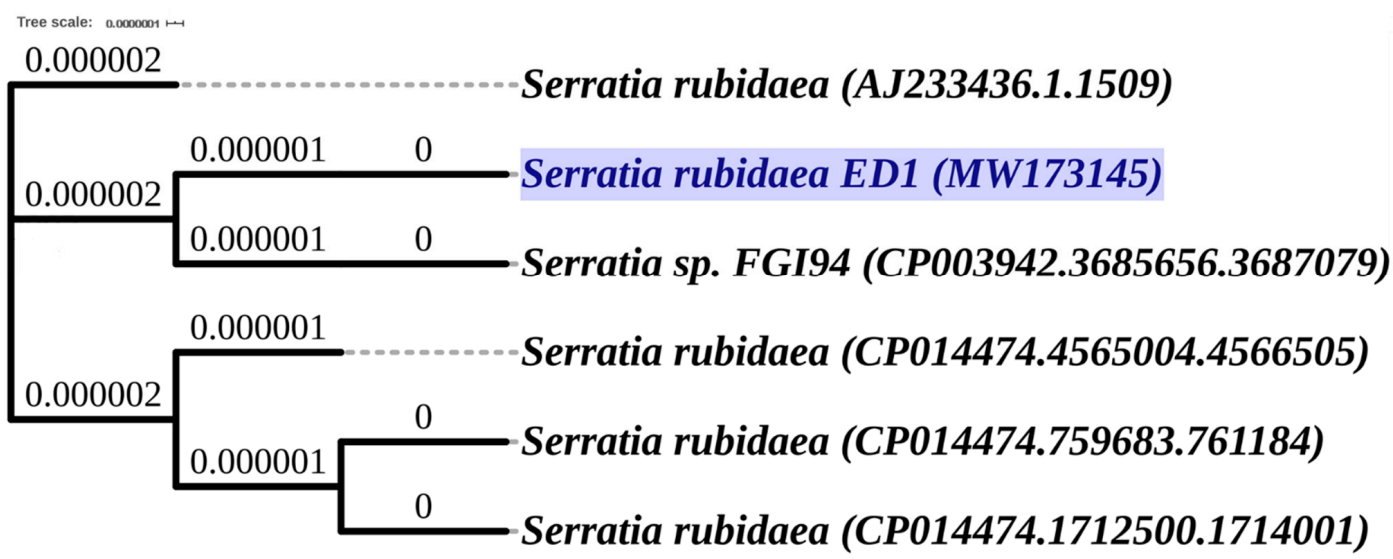

Figure 2. Phylogenetic tree of selected bacterium Serratia rubidaea ED1 (MW173145) based on the PHYLIP (PHYLogeny Inference Package) Neighbor-Joining method of the 16S rRNA gene sequences using (Unipro UGENE software, version 1.32.0. Branch lengths are displayed as age. The 16S rRNA gene sequences and tree of related species were downloaded from the High-Quality Ribosomal RNA database (SILVA).

The ability of the $S$. rubidaea ED1 strain to grow on plates containing various trace metals concentrations was also evaluated. Because of their great interest, cadmium, copper, and nickel were chosen. We found that $S$. rubidaea ED1 supported $\mathrm{CdSO}_{4}$ at $2000 \mu \mathrm{g} / \mathrm{mL}$, $\mathrm{CuO}_{4} \mathrm{~S} .5 \mathrm{H}_{2} \mathrm{O}$ at $1000 \mu \mathrm{g} / \mathrm{mL}$, and finally, $\mathrm{N}_{2} \mathrm{NiO}_{8}$ at $1000 \mu \mathrm{g} / \mathrm{mL}$. For both the positive and negative control strains, maximum tolerances were seen at $300 \mu \mathrm{g} / \mathrm{mL}, 1000 \mu \mathrm{g} / \mathrm{mL}$ and $1000 \mu \mathrm{g} / \mathrm{mL}$, of $\mathrm{CdSO}_{4}, \mathrm{~N}_{2} \mathrm{NiO}_{8}$, and $\mathrm{CuO}_{4} \mathrm{~S}$, respectively (Table 2).

Table 2. Summary of relevant extreme properties of isolated endophytic bacterium Serratia rubidaea ED1, the PGPR reference strain B. licheniformis QA1, and E. coli $\mathrm{DH} 5 \alpha(\mathrm{C}-)$.

\begin{tabular}{|c|c|c|c|c|c|}
\hline \multirow{3}{*}{ Species } & \multirow{3}{*}{$\begin{array}{c}\text { Maximum } \\
\text { Tolerable } \\
\text { Temperature }\end{array}$} & \multirow{3}{*}{$\begin{array}{l}\text { NaCl Tolerance } \\
\text { Range }(\%)\end{array}$} & \multirow{2}{*}{\multicolumn{3}{|c|}{$\begin{array}{c}\text { Heavy Metals Tolerance } \\
\text { Max Concentration }(\mu \mathrm{g} / \mathrm{mL})\end{array}$}} \\
\hline & & & & & \\
\hline & & & $\mathrm{CdSO}_{4}$ & $\mathrm{~N}_{2} \mathrm{NiO}_{8}$ & $\mathrm{CuO}_{4} \mathrm{~S}$ \\
\hline E. coli $\mathrm{DH} 5 \alpha(\mathrm{C}-)$ & $37^{\circ} \mathrm{C}$ & $0-3$ & 300 & 500 & 1000 \\
\hline $\begin{array}{l}\text { B. licheniformis } \\
\text { QA1 (C+) }\end{array}$ & $55^{\circ} \mathrm{C}$ & 0-11 & 200 & 1000 & 500 \\
\hline S. rubidaea ED1 & $42{ }^{\circ} \mathrm{C}$ & 0-9 & 2000 & 1000 & 1000 \\
\hline
\end{tabular}

Previously published B. licheniformis QA1 [32] was used as the PGPR reference strain (C+; Positive control) and E. coli $\mathrm{DH} 5 \alpha(\mathrm{C}-$; negative control).

(A)

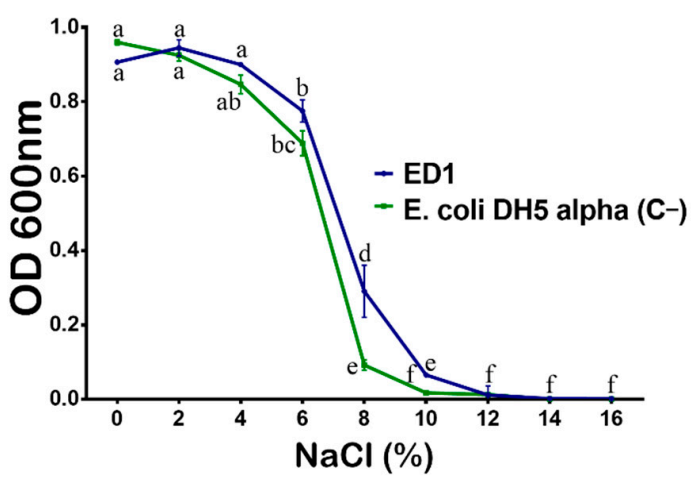

(B)

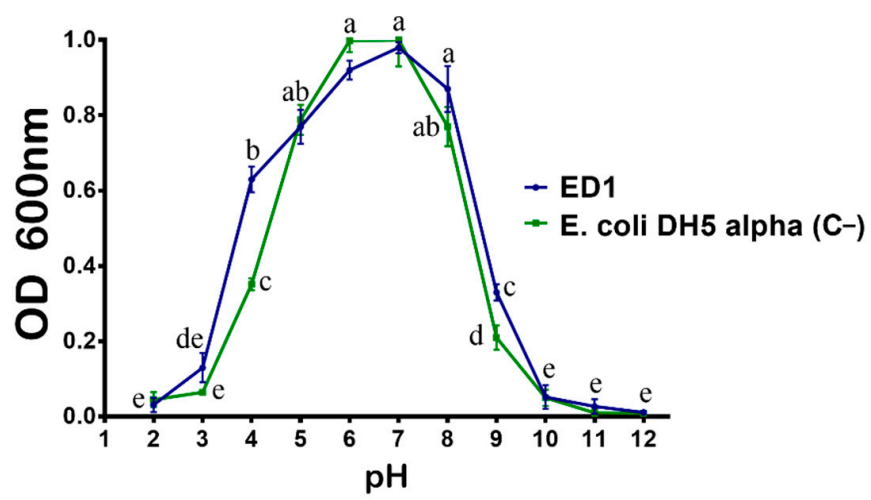

Figure 3. Effect of $\mathrm{NaCl}(\mathbf{A})$ and $\mathrm{pH}(\mathbf{B})$ on the growth of the S. rubidaea ED1 strain. Media inoculated with Esherichia coli $\mathrm{DH} 5 \alpha$ were used as a negative control $(\mathrm{C}-)$. The values represent means of three replicates $(n=3) \pm$ SD. The different letters in superscript (a-f) indicate the statistically significant difference at $95 \%$ between treatments. 


\subsection{Effect of $\mathrm{NaCl}$ on P solubilization by Strain S. rubidaea ED1}

Salinity is considered as one of the main factors influencing P solubilization by bacteria [76]. Here, we assessed the ability of ED1 strain to solubilize hydroxyapatite at increasing $\mathrm{NaCl}$ final concentrations: $0 \%, 4 \%$, and $8 \%$. P solubilization by the $\mathrm{S}$. rubidaea ED1 strain decreased following the increase of $\mathrm{NaCl}$ concentration $\left(R^{2}=0.87-0.99\right)$. In addition, $\mathrm{P}$ solubilization by ED1 was significantly increased over the incubation time from 5 to $10 \mathrm{DAI}$ (Figure $4 \mathrm{~A}$, Table 3). Soluble $\mathrm{PO}_{4}$ levels significantly deceased following the increase of $\mathrm{NaCl}$ concentration (Figure 4A) with correlation coefficients of up to -0.99 (Table 3). The mineral $\mathrm{P}$ was solubilized at its maximum at $0 \% \mathrm{NaCl}$ at $10 \mathrm{DAI}$ where it reached $1085.22 \pm 84.34 \mathrm{mg} / \mathrm{L}$ by ED1 strain and $307.81 \pm 20 \mathrm{mg} / \mathrm{L}$ by E. coli $\mathrm{DH} 5 \alpha(\mathrm{C}-)$. It turned out that compared to the $S$. rubidaea $\mathrm{ED} 1$ strain, $8 \% \mathrm{NaCl}$ has a greater reducing effect on E. coli DH5 $\alpha$ solubilizing capacity at 5DAI. Interestingly, the level of solubilized $\mathrm{P}$ under $8 \% \mathrm{NaCl}$ is the same as the one obtained at $0 \% \mathrm{NaCl}$ using ED1 strain. More precisely, soluble P reached $350.63 \pm 82.40 \mathrm{mg} / \mathrm{L}$ in $8 \% \mathrm{NaCl}$ medium using the $S$. rubidaea ED1 strain and $307.81 \pm 20 \mathrm{~mL} / \mathrm{L}$ in $0 \% \mathrm{NaCl}$ medium using E. coli DH5 $\alpha$. In salty media, solubilized $\mathrm{P}$ by ED1 increased from 5 to 10DAI, while no statistically significant increase was noticed in E. coli DH5 $\alpha$ (C-) (Figure 4A).

The solubilization of $\mathrm{P}$ by the endophyte strain was accompanied by a significant drop in $\mathrm{pH}$ of the culture supernatants in both saline and non-saline NBRIP media (Figure 4B). Highly negative correlations were noticed between soluble $p$ values and final $\mathrm{pH}$ of the supernatants $\left(r=0.9-0.99, R^{2}=0.82-0.98\right)$ (Table 3$)$. The maximum $\mathrm{pH}$ decline, $3.04 \pm 0.11$, was observed using ED1 in the non-saline medium at 10DAI and it proportionally increased with $\mathrm{NaCl}$ concentrations over the incubation period. For instance, at $8 \% \mathrm{NaCl}$, the $\mathrm{pH}$ at 10DAI was $5.86 \pm 0.29$ in E. coli DH5 $\alpha$, and $3.76 \pm 0.92$ in S. rubidaea ED1 strain (Figure 4B).

(A)

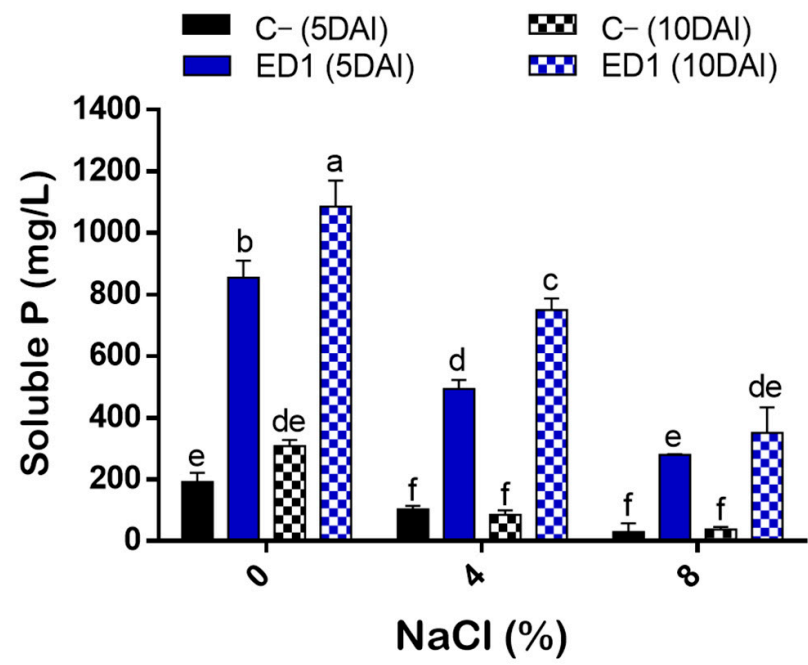

(B)

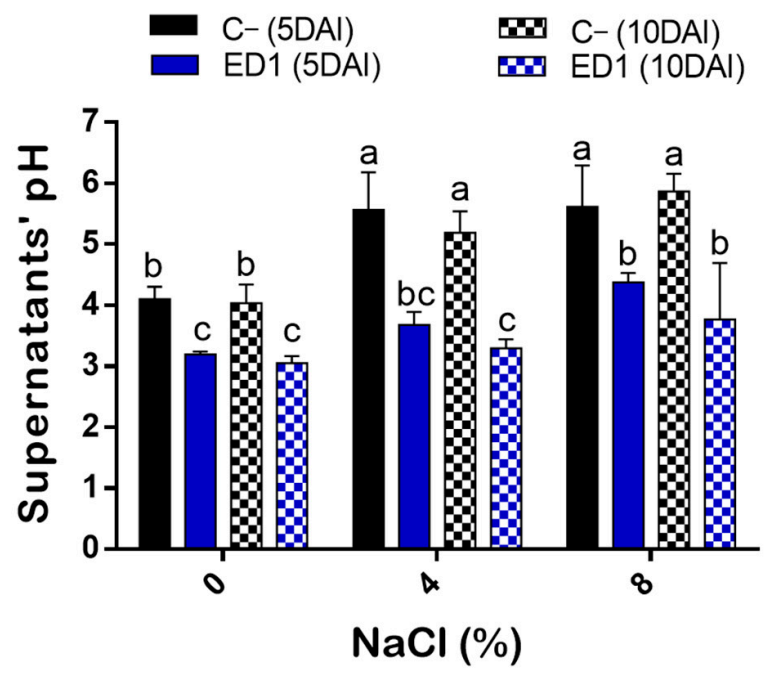

Figure 4. Quantitative determination of solubilized $\mathrm{P}\left(\mathrm{PO}_{4}\right)$ in the National Botanical Research Institute's phosphate (NBRIP) broth under salt stress conditions. (A) Solubilized P concentrations by the S. rubidaea ED1 strain and E. coli DH5 $\alpha(\mathrm{C}-$ ) at $0 \%, 4 \%$, and $8 \% \mathrm{NaCl}$ final concentrations. (B) $\mathrm{pH}$ variation of final culture supernatants. DAI means day after incubation. The values represent means of replicates $(n=3) \pm$ SD. The different letters in superscript (a-f) indicate the statistically significant difference at $95 \%$ between treatments. 
Table 3. Analysis of the variation of soluble P concentrations released by S. rubidaea ED1 and E. coli $\mathrm{DH} 5 \alpha$ strain as a function of $\mathrm{NaCl}$ levels and $\mathrm{pH}$ values.

\begin{tabular}{|c|c|c|c|c|}
\hline \multicolumn{5}{|c|}{ Soluble P vs. $\mathrm{NaCl}(\%)$} \\
\hline & $\mathrm{C}-(5 \mathrm{DAI})$ & ED1 (5DAI) & $\mathrm{C}-(10 \mathrm{DAI})$ & ED1 (10DAI) \\
\hline Coefficient of determination $\left(R^{2}\right)$ & 0.996 & 0.978 & 0.877 & 0.997 \\
\hline Correlation coefficient $(r)$ & -0.998 & -0.989 & -0.936 & -0.998 \\
\hline \multicolumn{5}{|c|}{ Soluble P vs. pH } \\
\hline & $\mathrm{C}-(5 \mathrm{DAI})$ & ED1 (5DAI) & $\mathrm{C}-(10 \mathrm{DAI})$ & ED1 (10DAI) \\
\hline Coefficient of determination $\left(R^{2}\right)$ & 0.820 & 0.940 & 0.957 & 0.983 \\
\hline Correlation coefficient $(r)$ & -0.905 & -0.969 & -0.978 & -0.991 \\
\hline
\end{tabular}

DAI: Day after incubation. C-: E. coli DH5 $\alpha$ strain used as negative control.

\subsection{Indole Acetic Acid Production by the Serratia Rubidaea ED1 Strain Is Partly L-Tryptophan Dependent}

The production of IAA by the S. Rubidaea ED1 strain correlated proportionally to added L-tryptophan concentrations $\left(r=0.88,0.99,0.98, R^{2}=0.77,0.99\right.$ and 0.96$)$ and to period of incubation $\left(r=0.95,0.99,0.99, R^{2}=0.91,0.98\right.$ and 0.99$)$ (Figure 5). IAA production was significantly higher using $0.5 \%$ L-tryptophan at day 11 (Figure $5 \mathrm{C}$ ) compared to $0.2 \% \mathrm{~L}$ tryptophan at day 7 . In the negative control media, IAA did not exceed $0.17 \pm 0.09 \mu \mathrm{g} / \mathrm{mL}$ over the three tested incubation periods (Figure 5A-C). Unexpectedly, IAA was produced even in the absence of L-tryptophan as the measured quantities were: $25.23 \pm 1.81 \mu \mathrm{g} / \mathrm{mL}$ at day 3 (Figure $5 \mathrm{~A}$ ), $66.79 \pm 18.88 \mu \mathrm{g} / \mathrm{mL}$ at day 7 (Figure $5 \mathrm{~B}$ ), and $76.47 \pm 17.7 \mu \mathrm{g} / \mathrm{mL}$ at day 11 (Figure 5C).

\section{(A)}

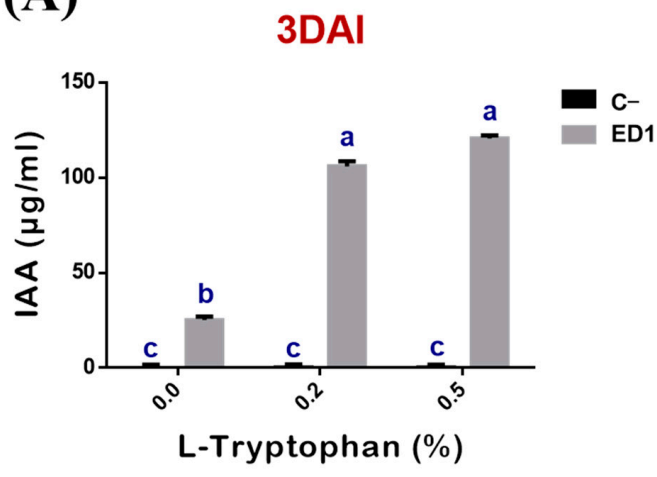

(B)

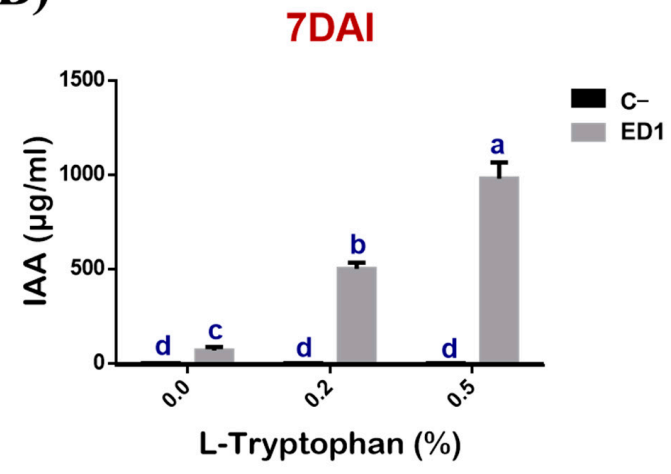

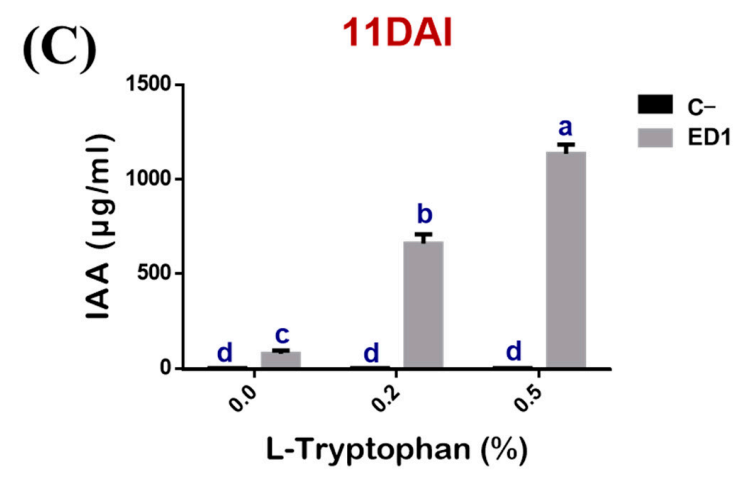

Figure 5. Kinetic of indole acetic acid (IAA) production by S. rubidaea ED1 with or without L-tryptophan addition. IAA determination was performed after 3 (A), 7 (B), and 11 (C) days of incubation. Uninoculated media were used as a negative control $(\mathrm{C}-)$. The values represent means of three replicates $(n=3) \pm \mathrm{SD}$. The different letters in superscript $(\mathrm{a}-\mathrm{d})$ indicate the statistically significant difference at $95 \%$ between treatments. 


\subsection{Strain Serratia rubidaea ED1 Exhibited Intrinsic Antibiotic Resistance}

Next, we evaluated the intrinsic resistance phenotype to antibiotics by choosing those that are frequently used in humans to tackle infectious diseases. Based on the Zone Size Interpretative Chart (ZSIC) and MIC strips (Figure 6), it turned out that the S. rubidaea ED1 strain is resistant to several antibiotics such as ciprofloxacin, ertapenem, meropenem, ampicillin, chloramphenicol, tetracycline, and spectinomycin, while Bacillus atrophaeus S8 strain resists only ceftazidim and ertapenem (Table 4, Figure 6).

\subsection{Strain Serratia rubidaea ED1 Enhanced Germination Rate and Seedlings Growth under Salty Amendment}

The quinoa seed germination rate of both inoculated and control seeds was gradually reduced along with an increasing of $\mathrm{NaCl}$ concentration, especially $24 \mathrm{~h}$ post incubation. The S. rubidaea ED1 strain significantly enhanced seed germination rate under non-saline $(0 \mathrm{mM} \mathrm{NaCl})$ and saline $(400 \mathrm{mM}$ or $2.32 \% \mathrm{NaCl}$ ) conditions by $36.35 \%$ (after $24 \mathrm{~h}$ incubation) and $390.39 \%$ (after $48 \mathrm{~h}$ incubation), respectively (Figure 7). Compared to non-saline treatment, $400 \mathrm{mM} \mathrm{NaCl}$ decreased seed germination by $58.87 \%$ in controls seeds and by $45.8 \%$ using S. rubidaea ED1 strain (Figure 8A,B, Table 5). At a moderate $\mathrm{NaCl}$ concentration $(200 \mathrm{mM}$ or $1.16 \% \mathrm{NaCl})$, the percentage of germination increased in a comparable manner to the control (Figure 8A,B). Inoculation with Serratia rubidaea ED1 increased the total length of seedlings under both non-saline and saline treatments. ED1 strain enhanced seedling length by $57.76,52.97$, and $376.19 \%$ under 0,200 , and $400 \mathrm{mM} \mathrm{NaCl}$, respectively (Figure 8C, Table 5). Likewise, quinoa seedlings showed 34.78 and $253.39 \%$ increase in dry weights under 0 and $400 \mathrm{mM} \mathrm{NaCl}$ treatments, respectively. Finally, the vigor index was significantly affected using the ED1 strain, especially under 0 and $400 \mathrm{mM} \mathrm{NaCl}$ treatment $(p<0.05)$ (Figure 8F).

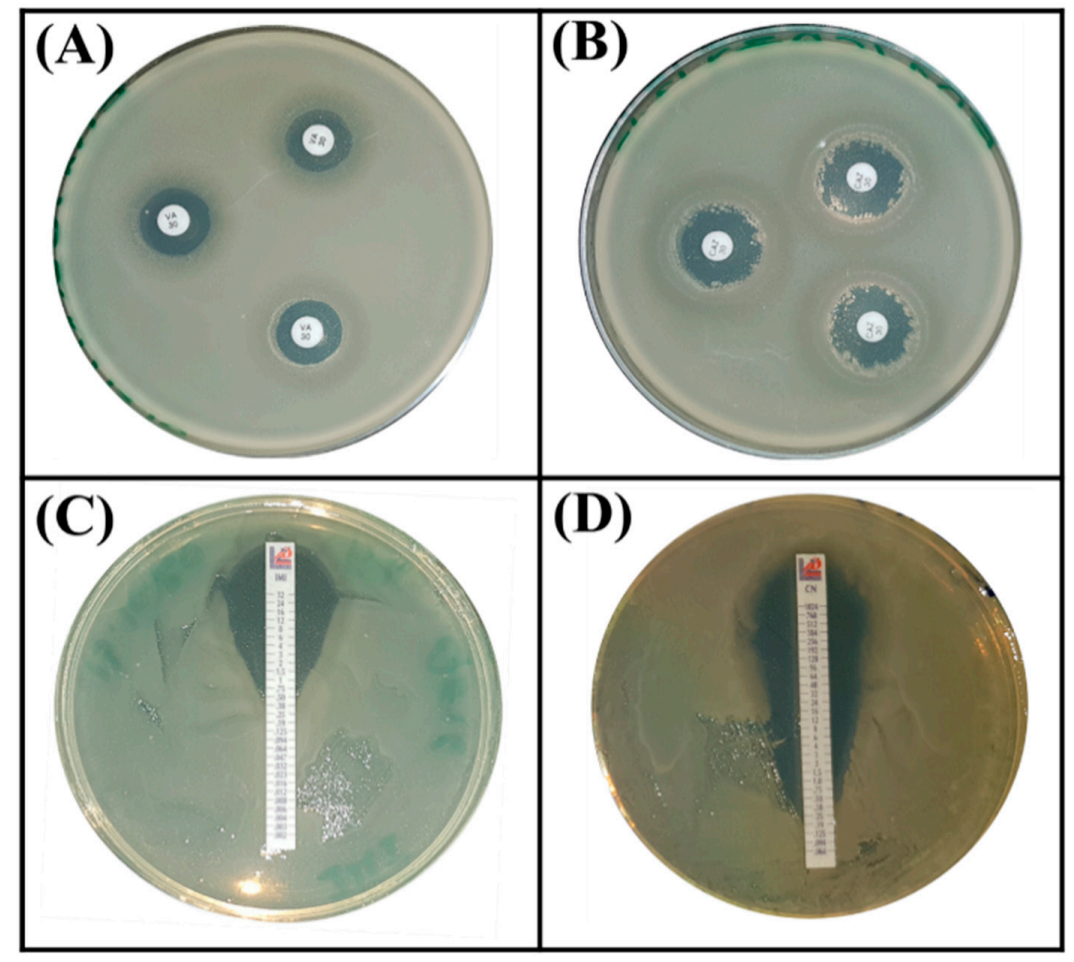

Figure 6. Antibiotic resistance assays using Serratia rubidaea ED1 strain on MHA (Mueller Hinton Agar, BIOKAR Diagnostics, BEAUVAIS, France) plates supplemented by antibiotic disc method (A,B) and Etest (C,D). (A) vancomycin, (B) ceftazidime, (C) imipenem, (D) gentamycin. 
Table 4. Antibiotic resistance profile of the S. rubidaea ED1 strain using disc diffusion, Etest, and antibiotic amended agar methods.

\begin{tabular}{|c|c|c|c|c|c|c|c|c|}
\hline \multicolumn{4}{|c|}{ Strain Etest (MIC in $\mu \mathrm{g} / \mathrm{mL})$} & \multicolumn{5}{|c|}{ Disc Diffusion Test (Zone of Inhibition in $\mathrm{mm}$ ) } \\
\hline & \multirow{2}{*}{ IMI } & \multirow{2}{*}{ CTX } & \multirow{2}{*}{$\mathrm{CN}$} & CAZ & CIP & MRP & ETP & VA \\
\hline & & & & $(30 \mu \mathrm{g})$ & $(10 \mu \mathrm{g})$ & $(10 \mu g)$ & $(10 \mu \mathrm{g})$ & $(30 \mu \mathrm{g})$ \\
\hline S. rubidaea ED1 & 2.5 & 1 & 0.125 & $18.66 \pm 0.57$ & $20 \pm 2.64$ * & $19.93 \pm 0.77^{*}$ & $24.6 \pm 1.32 *$ & $13.66 \pm 0.57$ \\
\hline B. atrophaeus S8 & 0.38 & 1.5 & 0.75 & $17.66 \pm 1.52 *$ & $30 \pm 3$ & $29.33 \pm 2.08$ & $21 \pm 1^{*}$ & NT \\
\hline E. coli $\mathrm{DH} 5 \alpha(\mathrm{C}-)$ & - & - & - & - & - & - & - & - \\
\hline \multicolumn{9}{|c|}{ Antibiotic amended agar method $(\mu \mathrm{g} / \mathrm{mL})$} \\
\hline & $\mathrm{AM}$ & CHL & STR & SPC & K & TET & & \\
\hline & 100 & 20 & 100 & 60 & 50 & 10 & & \\
\hline S. rubidaea ED1 & + & + & - & + & - & + & & \\
\hline B. atrophaeus S8 & - & - & - & - & - & - & & \\
\hline E. coli DH5 $\alpha(\mathrm{C}-)$ & - & - & - & - & - & - & & \\
\hline
\end{tabular}

The values represent means of three replicates $(n=3) \pm$ SD. MIC (Minimum Inhibitory Concentration), CAZ (ceftazidim), IMI (imipenem), CIP (ciprofloxacin), CTX (cefotaxim), CN (gentamycin), MRP (meropenem), ETP (ertapenem), VA (vancomycin), AM (ampicillin), CHL (chloramphenicol), STR (streptomycin), SPC (spectinomycin), K (kanamycin), TET (tetracycline), NT (Not tested). Asterisk symbols $\left({ }^{*}\right)$ and the ' + ' sign indicate resistance while the ' - ' sign indicates susceptibility. Strains Bacillus atrophaeus S8, and E. coli DH5 $\alpha(\mathrm{C}-)$ were used as controls.
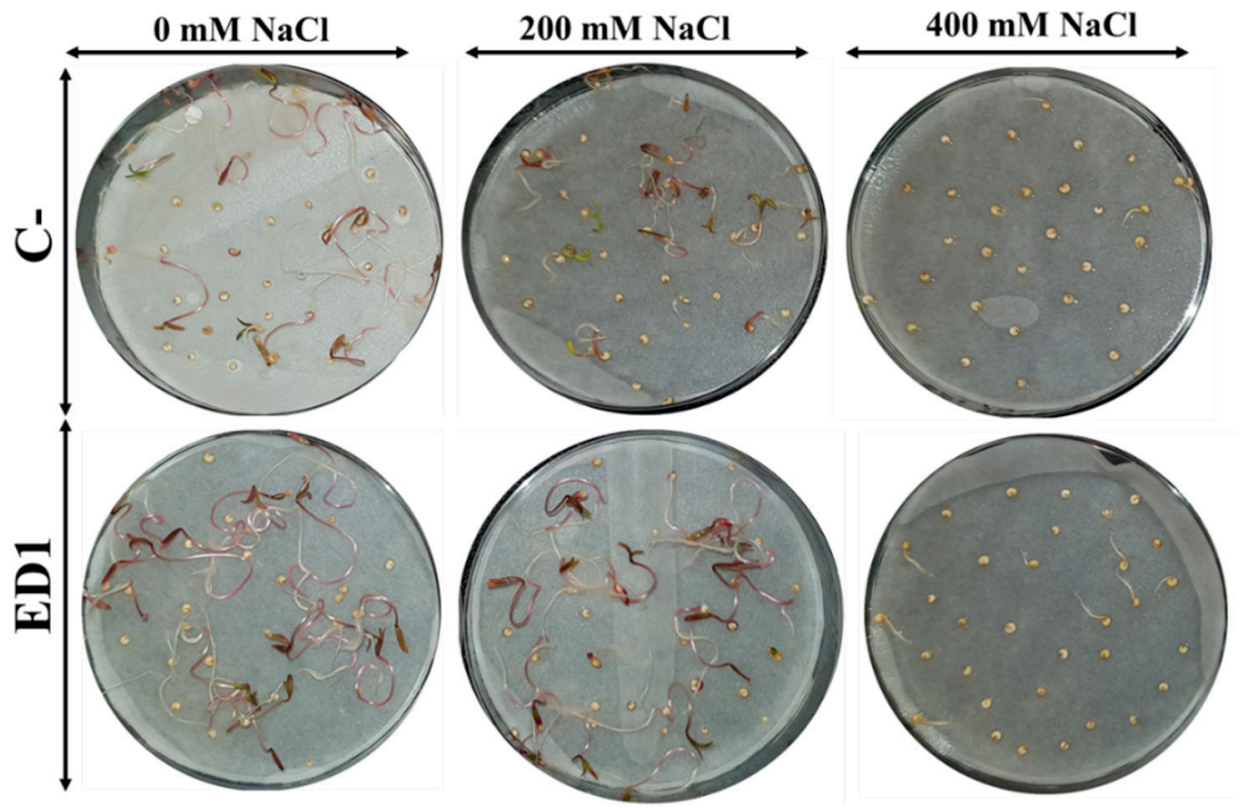

Figure 7. Effect of the Serratia rubidaea ED1 strain on quinoa seed germination and early growth seedlings under saline treatments. Seeds inoculated with phosphate-buffered saline (PBS) were used as a negative control $(\mathrm{C}-$ ). 


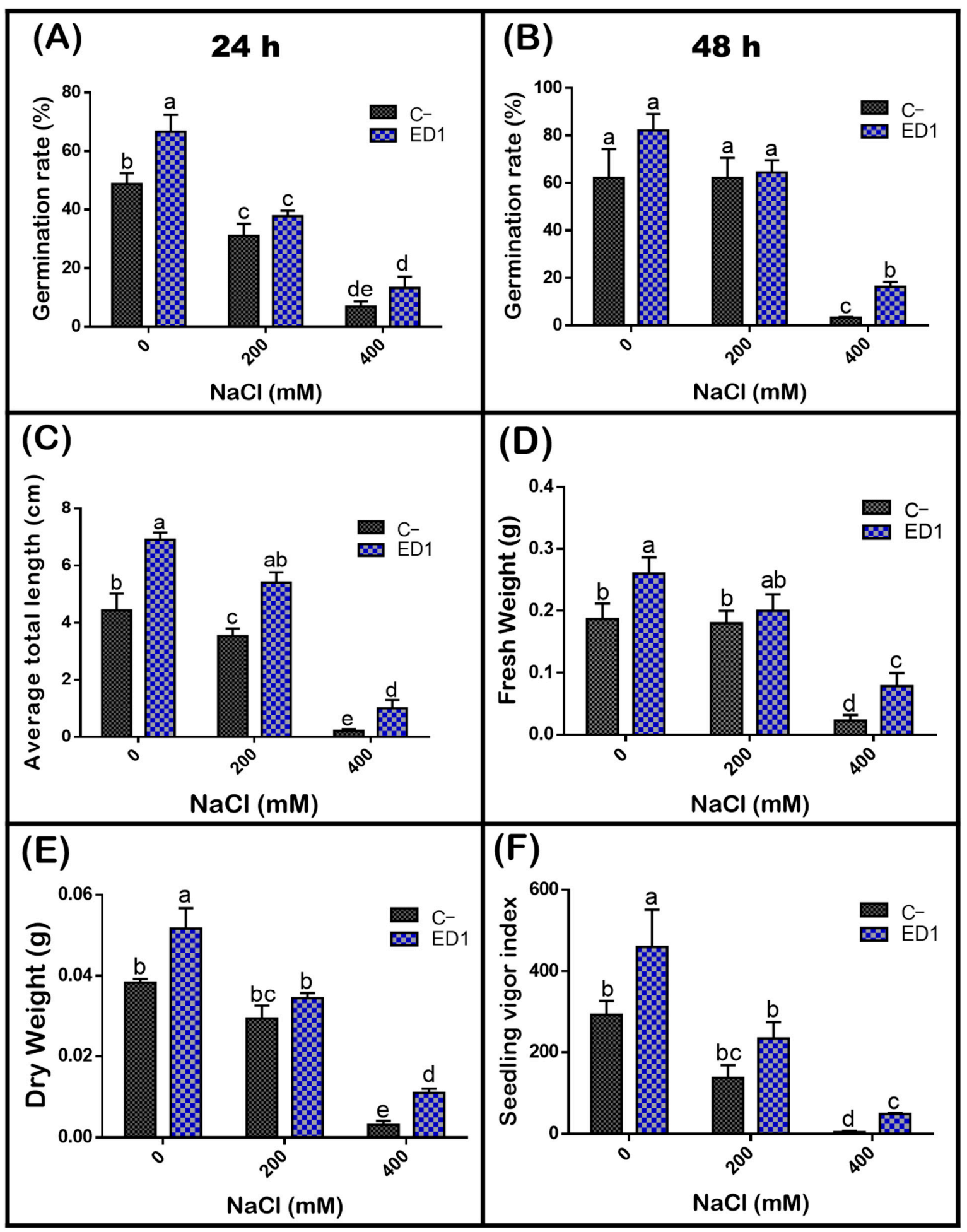

Figure 8. Effect of the S. rubidaea ED1 strain on quinoa seed germination parameters under different salinity treatments $(0$, 200 , and $400 \mathrm{mM} \mathrm{NaCl}$ ) after $48 \mathrm{~h}$ of incubation at $25^{\circ} \mathrm{C}$. C - (negative control; Seeds inoculated with phosphate-buffered saline (PBS)), ED1 (Seed treated with the ED1 strain): (A) Germination rate after $24 \mathrm{~h}$ of incubation, (B) germination rate after $48 \mathrm{~h}$ of incubation, (C) average of total length of seedlings, (D) average of fresh weight of seedlings, (E) average of dry weight of seedlings, and (F) seedling vigor index. The values represent means of three replicates $(n=3) \pm$ SD. The different letters in superscript (a-e) indicate the statistically significant difference at $95 \%$ between treatments. 
Table 5. Inoculation of quinoa seeds with the Serratia rubidaea ED1 strain enhanced the rate of seedling growth parameters.

\begin{tabular}{ccccccc}
\hline \multicolumn{7}{c}{ \% Increase } \\
\hline $\mathbf{N a C l}(\mathbf{m M})$ & Germination Rate $\mathbf{( 2 4} \mathbf{h})$ & Germination Rate $\mathbf{( 4 8} \mathbf{h})$ & Total Length & Fresh Weight & Dry Weight & Vigor Index \\
\hline 0 & 36.36 & 32.15 & 55.76 & 39.29 & 34.78 & 57.26 \\
200 & 21.46 & 3.59 & 52.97 & 11.11 & 17.05 & 39.45 \\
400 & 93.79 & 390.39 & 376.19 & 245.59 & 253.39 & 904.50 \\
\hline
\end{tabular}

Seeds inoculated with phosphate-buffered saline (PBS) were used as the growth reference (100\%). for each parameter.

\section{Discussion}

Alongside nitrogen $(\mathrm{N})$ and potassium $(\mathrm{K})$, phosphorus $(\mathrm{P})$ is one of the most limiting nutrients for crop yields, growth, and development. P deficiency in plants is usually translated by inhibited stem and root development, poor flowering, lack of seed and fruit formation etc. In last decades, the use of PGPB-based bio-inoculants as an alternative to chemical fertilizers has emerged [77]. In the present study, we identified an endophytic S. rubidaea ED1 bacterium from quinoa roots endosphere, a plant endowed with many phyto-beneficial attributes facing extreme growth stresses. Some PGP results of Serratia rubidaea ED1 were expected as they were reported in Serratia rubidaea alongside S. plymuthica, S. liquefaciens, S. proteamaculans, and S. nematodiphila, isolated from various environments niches [78]. PGP attributes of Serratia rubidaea (NR114716) associated with Origanum plants was reported for IAA and siderophores production, $\mathrm{P}$ solubilization, ACC-deaminase activity, and $\mathrm{N}$ fixation [79]. In addition, this strain improved growth performance parameters and biochemicals, and was considered as a potential bio-factor to engineer the essential oil constituents from aromatic plants [79]. The first and foremost activity we tested here was mineral $\mathrm{P}$ and $\mathrm{Zn}$ solubilization. Although reports on $\mathrm{P}$ and $\mathrm{Zn}$ solubilization by bacterial endophytes are scarce, we showed that $S$. rubidaea ED1 strain solubilized both mineral compounds of $\mathrm{P}$ and $\mathrm{Zn}$. Maximum $\mathrm{Zn}$ solubilization was recorded in $\mathrm{ZnO}$ compared to $\mathrm{Zn}_{3}\left(\mathrm{PO}_{4}\right)_{2}$, and $\mathrm{ZnCO}_{3}$ (Table 1). The mechanisms underlying this specificity remain unknown and very recently, endophytic Serratia sp. ZoB14 has been screened for dual $\mathrm{P}$ and $\mathrm{ZnO}$ solubilization [80]. Next, we showed that $S$. rubidaea ED1 grew on a N-free solid medium supporting its oligonitrophilic feature (Table 1) as previously reported in Serratia liquefaciens and Serratia marcescens [81,82]. Indeed, oligonitrophilic bacteria have broad substrate specificities that allow them to maintain their structure in low $\mathrm{N}$ environments [83]. However, other environmental factors, such as soil $\mathrm{pH}$, could greatly influence the oligonitrophilic function [84]. This confirms that Serratia rubidaea ED1 strain is more prone to oligonitrophilic conditions, e.g., plants' endosphere.

Around the world, $20 \%$ of cultivated and $33 \%$ of irrigated arable lands are affected by high salinity [85]. Induced salt tolerance in plants has been shown to be associated with various PGPR strains [32,86-88]. We demonstrated here that Serratia rubidaea ED1 grew up to $10 \% \mathrm{NaCl}$ (Figure 3). Taking advantage to this result, we next studied $\mathrm{P}$ solubilization under salty conditions. The quantity of orthophosphates $\left(\mathrm{PO}_{4}\right)$ released from hydroxyapatite by $\mathrm{S}$. rubidaea $\mathrm{ED} 1$ decreased with the increase of $\mathrm{NaCl}$ concentration. However, substantial amount of soluble P (up to $750 \mathrm{mg} / \mathrm{L}$ ) was detected at 10DAI using $4 \% \mathrm{NaCl}$ final concentration. Maximum soluble P level, $1085.22 \pm 84.34 \mathrm{mg} / \mathrm{L}$, was seen in $0 \% \mathrm{NaCl}$ media at 10DAI (Figure 4). In salty media, the increased P release between days 5 and 10 suggests the adaptation of Serratia rubidaea ED1 to the salty medium, as previously reported for Bacillus megaterium [51]. Our result is in-line with the reported data on the endophytic Pseudomonas fluorescens that solubilized up to $1312 \mathrm{mg} / \mathrm{L}$ in non-saline NBRIP medium [46]. As expected, P solubilization was accompanied by a $\mathrm{pH}$ decrease which remained almost unchanged under salt treatment. This finding is likely attributed to organic acids production [89].

Bacteria from any environment are exposed to abiotic stress, exemplified by salinity, $\mathrm{pH}$, temperature, trace elements, nutrient deficiency, and biotic stress such as toxic metabolites, pathogens, competing microorganisms [90]. To cope with these stresses, bacteria use several adaptative strategies to modify their signalization pathways [51]. Salt level is one of 
the main parameters affecting the growth rate and metabolism of microorganisms and several reports indicated the positive impact of halotolerant microorganisms on plant growth At present, PGPB are suggested to enhance the productivity of plants facing salinity and can be exploited to sustain saline agroecosystems [20]. In this study, salt tolerance of $S$. rubidaea $\mathrm{ED} 1$ to $\mathrm{NaCl}$ was about $10 \%$, while total growth arrest happened at $12 \%$ under hyper osmotic conditions (Figure 3). Salt-tolerant bacteria activate osmoadaptation pathways mainly by synthesizing compatible solutes and/or accumulation of $\mathrm{K}^{+}$to overcome the $\mathrm{Na}^{+}$ions associated toxicity [91]. The excess of sodium ions affects the bacterial enzymes activity [92]. In addition, bacterial exopolysaccharides (EPS), antioxidant enzymes, and ACC deaminase activity are among the strongest salt stress-adapting mechanisms [21].

The capacity of selected endophytic bacterium to solubilize unavailable nutrients such as $\mathrm{P}$ and $\mathrm{Zn}$ and grow in low nitrogen medium is supportive to further investigate its plant growth potential by boosting plant nutrition. To further confirm the halotolerance property of $S$. rubidaea ED1 strain, we performed a seed germination assay and revealed that inoculation of quinoa seeds enhanced seeds germination and seedlings growth under $400 \mathrm{mM}(2.32 \%) \mathrm{NaCl}$. Noticeably, germination rate in both inoculated and non-inoculated seeds were inversely proportional to the increase of $\mathrm{NaCl}$ (Figures 7 and 8), as previously reported [93]. Indeed, inoculation of quinoa seeds showed a prominent effect on vigor index (904.50\% increase) (Table 5), pointing out the mitigation of salt stress in both assays. To our knowledge, this finding represents the first report stating that Serratia rubidaea promoted seeds germination and seedlings growth under salty treatments. Comparatively, a study on Ligustrum sinense seeds was conducted by increasing $\mathrm{NaCl}$ concentrations $(0-500 \mathrm{mM})$ using strains: Isoptericola dokdonensis, Arthrobacter soli, Streptomyces pactum, and Bacillus flexus. The latter induced seeds germination by reaching $100 \%$ under $300-500 \mathrm{mM} \mathrm{NaCl}$ treatment [93]. Sorghum seeds inoculated with endorhizospheric Serratia sp. promoted seedlings growth [94]. The increase in seeds germination is likely attributed to the production of phytohormones such IAA [95]. Other studies reported the promoting role of Bacillus and Pseudomonas in seed germination, root development, and plant growth [96] of various crops including wheat, rice, and sugarcane [97]. Indeed, stimulation of seeds germination in the presence of IAA producing bacteria has been described [75]. Here, IAA production by Serratia rubidaea ED1 was seen even in the absence of L-Tryptophan supplementation (Figure 5). However, in L-tryptophan-supplemented broth, production of IAA increased significantly (Figure 5), corroborating previous finding on Serratia species including S. rubidaea highlighting that IAA signaling pathways are either auxin-dependent, auxin-independent, or tryptophan-independent $[78,98]$. Besides, other halotolerant bacteria species isolated from halophytic plant in coastal soils in Korea, enhanced plant growth under saline stress. In this case, plant growth was linked to the activity of the ACC deaminase that reduced ethylene production [99]. Additionally, it was reported that the halophyte Salicornia brachiate induced plant growth by withstanding a high level of salt [100]. More mechanisms by which microorganisms improve physiological response of plants under salt stress were described [101,102]. These include osmolytes accumulation which regulate water homeostasis, hormonal root-shoot signaling inducing salt tolerance in plants, modulation of the source-sink relationships for plant energetics, nutrients and toxic ions uptake by root by modifying host plant physiology, physical barriers around the roots, or by reducing foliar accumulation of toxic ions [101,102].

In another part of this study, we checked the ability of S. rubidaea ED1 to resist $\mathrm{pH}$ and to withstand trace elements. It was found to grow from $\mathrm{pH} 4$ to 9 but at a significantly low rate compared to optimal pH 7 (Figure 3). Compared to other PGP strains such as Bacillus megaterium, Staphylococcus haemolyticus, and Bacillus licheniformis [52], ED1 strain tolerates slightly higher acidity, suggesting its ability to grow in acidic soils [103]. Accumulation of trace elements in the environment represent a major concern to public health and agriculture [104]. We found that ED1 strain survives at $2 \mathrm{mg} / \mathrm{L}$ of $\mathrm{CdSO}_{4}$, and $1 \mathrm{mg} / \mathrm{L}$ of either $\mathrm{CuO}_{4} \mathrm{~S} .5 \mathrm{H}_{2} \mathrm{O}$ or $\mathrm{N}_{2} \mathrm{NiO}_{8}$ (Table 2). In the same range, Planomicrobium chinense and Bacillus cereus tolerate $\mathrm{Cd}(1.5 \mathrm{mg} / \mathrm{L})$ and $\mathrm{Ni}(1 \mathrm{mg} / \mathrm{L})$ by accumulating 
heavy metals upon chelating agents release that affect their mobility and availability which consequently enhance phytoremediation and nutrient transformation [105]. For example, Serratia marcescens was shown to assist phytoremediation of metals via the reduction of the toxic chromium (VI) to the less soluble and less toxic chromium (III) [106].

To be an effective biofertilizer, PGPR must survive, resist, and colonize root surface and/or interior to establish itself at population densities required to induce beneficial effects on the host plant. We assessed the intrinsic antibiotic resistance of selected strain on $\mathrm{MH}$ agar plates. Surprisingly, this topic is very often neglected in agriculture. Here, we report that $S$. rubidaea ED1 is resistant to seven antibiotics, frequently used to treat infection diseases in humans such as ciprofloxacin, ertapenem, meropenem, ampicillin, chloramphenicol, tetracycline, and spectinomycin (Table 4). Our finding supports previous findings for another Serratia rubidaea strain conferring resistance to ampicillin, tetracycline, gentamycin, penicillin, vancomycin, and streptomycin [107-109]. The novelty here is that the list of antibiotics can be extended to five additional antibiotics, namely, ciprofloxacin, ertapenem, meropenem, chloramphenicol, and spectinomycin. It is well established that soil, food, and water are the habitats of the Serratia rubidaea strain. Interestingly, it was also found among clinical specimens as a nonpathogenic bacterium [110]. However, infection by Serratia rubidaea was reported in immunocompromised patients [111,112]. In 2016, the first complete sequence of the genome of Serratia rubidaea (СР014474) was isolated from a patient in China [113]. Sequence analysis revealed the presence of several antibiotic resistance genes (ARG) encoding metallo-beta-lactamase, chloramphenicol, and aminoglycoside phosphotransferase. Other Serratia strains such as S. marcescens FGI94, S. fonticola DSM 4576, and S. ficaria showed also multi-resistances to antibiotics [114-116]. Thus, the emerging question is how to consider the two-blade weapons of PGP bacterial strains exhibiting intrinsic resistance to several antibiotics. On the one hand, they can be used either as markers to assess bacteria survival either in vitro or in vivo [117,118], and to help bacteria surviving and competing in native and open microbial environmental niches [35]. On the other hand, their use may represent potential risks by disseminating ARG to neighboring bacteria, plant, animals, and later, to humans [119]. Having said that, the alterable functional and adaptive behavior of resistant strains originating from different environments can differ in genome expression profiles, accessory genome sequences, antibiotic resistance pattern, and virulence activities. In addition, polyphasic approaches, mainly multi-locus sequence typing, discriminatory genotyping methods such as $r e c N$ sequencing, and genome hybridization, showed that a same strain (e.g., Pseudomonas aeruginosa) could be a singleton among a large group of closely related strains, clustering distantly from the typical clinical isolates $[90,120,121]$. The occurrence of $S$. rubidaea in human specimens is rare, and there are no data suggesting that it is of a clinical significance [122]. Recently, rhamnolipid biosurfactant production by Serratia rubidaea SNAU02 was shown to act as an anti-Fusarium wilt of eggplant [123]. Production of prodigiosin and pyrrolnitrin by Serratia rubidaea C27 represents the main antifungal activity mechanisms [124]. In addition, S. rubidaea species were isolated from infected pepper fruits as a causal agent of splotches. This phyto-pathogenicity was attributed to the liberation of extracellular enzymes playing a role during the host infection including protease, lipase, polygalacturonase, and alkaline phosphatase that degrade plant cell wall and membrane constituents. However, their production is inducible and usually dependent on several environmental factors [125].

\section{Conclusions}

The present study corroborates previous findings and bring new insights on the role of endophytic bacteria in mitigating stresses in agriculture. Our results shed light on the role of the newly isolated S. rubidaea ED1 strain to mitigate salt stress. Further investigations on plant growth promotion under large-scale experiments would be paramount to uncover various mechanisms and potential applications of Serratia rubidaea ED1 in agriculture. Besides, there is a growing need to remediate the heavy metals from contaminated soils using various microbial accumulators capable of growing in heavy metals contaminated 
soils [126]. Hence, to follow-up the present work, more studies should address the potential application of $S$. rubidaea ED1 in sustainable rehabilitation of heavy metals contaminated arable lands and to spotlight the underpinning mechanisms. Lastly, our work raises questions on a neglected issue related to the risk in using PGPR bacteria conferring resistance to many antibiotics for crop improvement.

Author Contributions: Conceptualization, L.B. \& A.A.; Funding acquisition, L.B.; Investigation, I.M. and L.B.; Methodology, I.M. \& L.B., Project administration, L.B.; Supervision, L.B. \& M.H.; Validation L.B. \& A.A.; Writing—original draft, I.M.; Writing—review \& editing, A.A. \& L.B. All authors have read and agreed to the published version of the manuscript.

Funding: This work was supported by welcome grants from the Mohammed VI Polytechnic University (UM6P) of Ben Guerir, Morocco.

Acknowledgments: We thank Fatiha Laalouhmi for technical assistance and Mohamed Hijri for helpful discussion and facilities.

Conflicts of Interest: The authors declare no conflict of interest.

\section{References}

1. Rosenblueth, M.; Martínez-Romero, E. Bacterial endophytes and their interactions with hosts. Mol. Plant-Microbe Interact. 2006, 19, 827-837. [CrossRef]

2. Wilson, D. Endophyte: The evolution of a term, and clarification of its use and definition. Oikos 1995, 274-276. [CrossRef]

3. Hardoim, P.R.; Van Overbeek, L.S.; Berg, G.; Pirttilä, A.M.; Compant, S.; Campisano, A.; Döring, M.; Sessitsch, A. The hidden world within plants: Ecological and evolutionary considerations for defining functioning of microbial endophytes. Microbiol. Mol. Biol. Rev. 2015, 79, 293-320. [CrossRef]

4. Kandel, S.L.; Joubert, P.M.; Doty, S.L. Bacterial endophyte colonization and distribution within plants. Microorganisms 2017, 5, 77. [CrossRef] [PubMed]

5. Xia, Y.; DeBolt, S.; Dreyer, J.; Scott, D.; Williams, M.A. Characterization of culturable bacterial endophytes and their capacity to promote plant growth from plants grown using organic or conventional practices. Front. Plant Sci. 2015, 6, 490. [CrossRef]

6. Ma, Y.; Prasad, M.N.V.; Rajkumar, M.; Freitas, H. Plant growth promoting rhizobacteria and endophytes accelerate phytoremediation of metalliferous soils. Biotechnol. Adv. 2011, 29, 248-258. [CrossRef] [PubMed]

7. Liu, H.; Carvalhais, L.C.; Crawford, M.; Singh, E.; Dennis, P.G.; Pieterse, C.M.; Schenk, P.M. Inner plant values: Diversity, colonization and benefits from endophytic bacteria. Front. Microbiol. 2017, 8, 2552. [CrossRef] [PubMed]

8. Martinez-Medina, A.; Flors, V.; Heil, M.; Mauch-Mani, B.; Pieterse, C.M.J.; Pozo, M.J.; Ton, J.; van Dam, N.M.; Conrath, U. Recognizing Plant Defense Priming. Trends Plant Sci. 2016, 21, 818-822. [CrossRef]

9. Chanway, C. Inoculation of tree roots with plant growth promoting soil bacteria: An emerging technology for reforestation. For. Sci. 1997, 43, 99-112. [CrossRef]

10. Bent, E.; Chanway, C.P. The growth-promoting effects of a bacterial endophyte on lodgepole pine are partially inhibited by the presence of other rhizobacteria. Can. J. Microbiol. 1998, 44, 980-988. [CrossRef]

11. McInroy, J.; Kloepper, J. Novel Bacterial Taxa Inhabiting Internal Tissues of Sweet Corn and Cotton; CSIRO: Melbourne, Australia, 1994; pp. 190-238.

12. Liu, H.; Carvalhais, L.C.; Schenk, P.M.; Dennis, P.G. Effects of jasmonic acid signalling on the wheat microbiome differ between body sites. Sci. Rep. 2017, 7, 1-8. [CrossRef]

13. Marques, J.M.; da Silva, T.F.; Vollú, R.E.; de Lacerda, J.R.M.; Blank, A.F.; Smalla, K.; Seldin, L. Bacterial endophytes of sweet potato tuberous roots affected by the plant genotype and growth stage. Appl. Soil Ecol. 2015, 96, 273-281. [CrossRef]

14. Ferrando, L.; Fernández Scavino, A. Strong shift in the diazotrophic endophytic bacterial community inhabiting rice (Oryza sativa) plants after flooding. FEMS Microbiol. Ecol. 2015, 91. [CrossRef] [PubMed]

15. Magnani, G.; Cruz, L.; Weber, H.; Bespalhok, J.; Daros, E.; Baura, V.; Yates, M.; Monteiro, R.; Faoro, H.; Pedrosa, F. Cultureindependent analysis of endophytic bacterial communities associated with Brazilian sugarcane. Genet. Mol. Res 2013, 12, 4549-4558. [CrossRef] [PubMed]

16. De Oliveira Costa, L.E.; de Queiroz, M.V.; Borges, A.C.; de Moraes, C.A.; de Araújo, E.F. Isolation and characterization of endophytic bacteria isolated from the leaves of the common bean (Phaseolus vulgaris). Braz. J. Microbiol. 2012, 43, 1562-1575. [CrossRef]

17. Ortuño, N.; Claros, M.; Gutiérrez, C.; Angulo, M.; Castillo, J. Bacteria associated with the cultivation of quinoa in the Bolivian Altiplano and their biotechnological potential. Rev. Agric. 2014, 53, 53-61.

18. Reinhold-Hurek, B.; Bünger, W.; Burbano, C.S.; Sabale, M.; Hurek, T. Roots shaping their microbiome: Global hotspots for microbial activity. Annu. Rev. Phytopathol. 2015, 53, 403-424. [CrossRef] 
19. Ramos-Solano, B.; García, J.A.L.; Garcia-Villaraco, A.; Algar, E.; Garcia-Cristobal, J.; Mañero, F.J.G. Siderophore and chitinase producing isolates from the rhizosphere of Nicotiana glauca Graham enhance growth and induce systemic resistance in Solanum lycopersicum L. Plant Soil 2010, 334, 189-197. [CrossRef]

20. Bunsangiam, S.; Sakpuntoon, V.; Srisuk, N.; Ohashi, T.; Fujiyama, K.; Limtong, S. Biosynthetic pathway of indole-3-acetic acid in basidiomycetous yeast Rhodosporidiobolus fluvialis. Mycobiology 2019, 47, 292-300. [CrossRef]

21. Egamberdieva, D.; Wirth, S.; Bellingrath-Kimura, S.D.; Mishra, J.; Arora, N.K. Salt-Tolerant Plant Growth Promoting Rhizobacteria for Enhancing Crop Productivity of Saline Soils. Front. Microbiol. 2019, 10, 2791. [CrossRef]

22. Munns, R. Comparative physiology of salt and water stress. Plant Cell Environ. 2002, 25, 239-250. [CrossRef]

23. Upadhyay, S.; Singh, J.; Singh, D. Exopolysaccharide-producing plant growth-promoting rhizobacteria under salinity condition. Pedosphere 2011, 21, 214-222. [CrossRef]

24. Ashraf, M.; Athar, H.R.; Harris, P.J.C.; Kwon, T.R. Some Prospective Strategies for Improving Crop Salt Tolerance. In Advances in Agronomy; Academic Press: Cambridge, MA, USA, 2008; Volume 97, pp. 45-110.

25. Niu, X.; Song, L.; Xiao, Y.; Ge, W. Drought-Tolerant Plant Growth-Promoting Rhizobacteria Associated with Foxtail Millet in a Semi-arid Agroecosystem and Their Potential in Alleviating Drought Stress. Front. Microbiol. 2018, 8. [CrossRef]

26. Bashan, Y. Inoculants of plant growth-promoting bacteria for use in agriculture. Biotechnol. Adv. 1998, 16, 729-770. [CrossRef]

27. Cassán, F.; Maiale, S.; Masciarelli, O.; Vidal, A.; Luna, V.; Ruiz, O. Cadaverine production by Azospirillum brasilense and its possible role in plant growth promotion and osmotic stress mitigation. Eur. J. Soil Biol. 2009, 45, 12-19. [CrossRef]

28. Bal, H.B.; Nayak, L.; Das, S.; Adhya, T.K. Isolation of ACC deaminase producing PGPR from rice rhizosphere and evaluating their plant growth promoting activity under salt stress. Plant Soil 2013, 366, 93-105. [CrossRef]

29. Goswami, D.; Dhandhukia, P.; Patel, P.; Thakker, J.N. Screening of PGPR from saline desert of Kutch: Growth promotion in Arachis hypogea by Bacillus licheniformis A2. Microbiol. Res. 2014, 169, 66-75. [CrossRef] [PubMed]

30. Upadhyay, S.; Singh, D. Effect of salt-tolerant plant growth-promoting rhizobacteria on wheat plants and soil health in a saline environment. Plant Biol. 2015, 17, 288-293. [CrossRef]

31. Bal, H.B.; Das, S.; Dangar, T.K.; Adhya, T.K. ACC deaminase and IAA producing growth promoting bacteria from the rhizosphere soil of tropical rice plants. J. Basic Microbiol. 2013, 53, 972-984. [CrossRef] [PubMed]

32. Mahdi, I.; Fahsi, N.; Hafidi, M.; Allaoui, A.; Biskri, L. Plant Growth Enhancement using Rhizospheric Halotolerant Phosphate Solubilizing Bacterium Bacillus licheniformis QA1 and Enterobacter asburiae QF11 Isolated from Chenopodium quinoa Willd. Microorganisms 2020, 8, 948. [CrossRef] [PubMed]

33. Singh, R.P.; Jha, P.N. Alleviation of salinity-induced damage on wheat plant by an ACC deaminase-producing halophilic bacterium Serratia sp. SL-12 isolated from a salt lake. Symbiosis 2016, 69, 101-111. [CrossRef]

34. Wellington, E.M.H.; Boxall, A.B.A.; Cross, P.; Feil, E.J.; Gaze, W.H.; Hawkey, P.M.; Johnson-Rollings, A.S.; Jones, D.L.; Lee, N.M.; Otten, W.; et al. The role of the natural environment in the emergence of antibiotic resistance in Gram-negative bacteria. Lancet Infect. Dis. 2013, 13, 155-165. [CrossRef]

35. Cray, J.A.; Bell, A.N.; Bhaganna, P.; Mswaka, A.Y.; Timson, D.J.; Hallsworth, J.E. The biology of habitat dominance; can microbes behave as weeds? Microb. Biotechnol. 2013, 6, 453-492. [CrossRef] [PubMed]

36. Vega-Galvez, A.; Miranda, M.; Vergara, J.; Uribe, E.; Puente, L.; Martinez, E.A. Nutrition facts and functional potential of quinoa (Chenopodium quinoa willd.), an ancient Andean grain: A review. J. Sci. Food Agric. 2010, 90, 2541-2547. [CrossRef] [PubMed]

37. Benlhabib, O.; Jacobsen, S.-E.; Jellen, E.N.; Maughan, P.J.; Choukr-Allah, R. Status of quinoa production and research in Morocco. In State of the Art Report on Quinoa around the World in 2013; Bazile, D., Bertero, H.D., Nieto, C., Eds.; Food and Agriculture Organization of the United Nations Romz: Quebec City, QC, Canada, 2015; pp. 178-491.

38. Jacobsen, S.-E.; Mujica, A.; Jensen, C. The resistance of quinoa (Chenopodium quinoa Willd.) to adverse abiotic factors. Food Rev. Int. 2003, 19, 99-109. [CrossRef]

39. Nowak, V.; Du, J.; Charrondiere, U.R. Assessment of the nutritional composition of quinoa (Chenopodium quinoa Willd.). Food Chem. 2016, 193, 47-54. [CrossRef]

40. Jacobsen, S.-E. The worldwide potential for quinoa (Chenopodium quinoa Willd.). Food Rev. Int. 2003, 19, 167-177. [CrossRef]

41. Filho, A.M.M.; Pirozi, M.R.; Borges, J.T.D.S.; Pinheiro Sant'Ana, H.M.; Chaves, J.B.P.; Coimbra, J.S.D.R. Quinoa: Nutritional, functional, and antinutritional aspects. Crit. Rev. Food Sci. Nutr. 2017, 57, 1618-1630. [CrossRef]

42. Hirich, A.; Choukr-Allah, R.; Jacobsen, S.-E. Quinoa in Morocco-Effect of Sowing Dates on Development and Yield. J. Agron. Crop Sci. 2014, 200. [CrossRef]

43. Araújo, W.; Lima, A.D.S.; Azevedo, J.; Marcon, J.; Sobral, J.; Lacava, P. Manual: Isolamento de microrganismos endofíticos. Piracicaba Calq 2002, 1,86.

44. González-Teuber, M.; Vilo, C.; Bascuñán-Godoy, L. Molecular characterization of endophytic fungi associated with the roots of Chenopodium quinoa inhabiting the Atacama Desert, Chile. Genom. Data 2017, 11, 109-112. [CrossRef]

45. Nautiyal, C.S. An efficient microbiological growth medium for screening phosphate solubilizing microorganisms. FEMS Microbiol. Lett. 1999, 170, 265-270. [CrossRef]

46. Oteino, N.; Lally, R.D.; Kiwanuka, S.; Lloyd, A.; Ryan, D.; Germaine, K.J.; Dowling, D.N. Plant growth promotion induced by phosphate solubilizing endophytic Pseudomonas isolates. Front. Microbiol. 2015, 6, 745. [CrossRef]

47. Hill, J.E.; Hemmingsen, S.M.; Town, J.R. Strong PCR Primers and Primer Cocktails. U.S. Patent 7507535B2, 24 March 2009. 
48. Oliver, F. 25 years of serving the community with ribosomal RNA gene reference databases and tools. J. Biotechnol. 2017. [CrossRef]

49. Okonechnikov, K.; Golosova, O.; Fursov, M.; Team, T.U. Unipro UGENE: A unified bioinformatics toolkit. Bioinformatics 2012, 28, 1166-1167. [CrossRef]

50. Patel, K.S.; Naik, J.H.; Chaudhari, S.; Amaresan, N. Characterization of culturable bacteria isolated from hot springs for plant growth promoting traits and effect on tomato (Lycopersicon esculentum) seedling. Comptes Rendus Biol. 2017, 340, 244-249. [CrossRef] [PubMed]

51. Thant, S.; Aung, N.; Aye, O. Phosphate solubilization of Bacillus megaterium isolated from non-saline soils under salt stressed conditions. J. Bacteriol. Mycol. Open Access 2018, 6, 335-341. [CrossRef]

52. Biswas, J.; Banerjee, A.; Rai, M.; Naidu, R.; Biswas, B.; Vithanage, M.; Chandra Dash, M.; Sarkar, S.; Meers, E. Potential application of selected metal resistant phosphate solubilizing bacteria isolated from the gut of earthworm (Metaphire posthuma) in plant growth promotion. Geoderma 2018, 330, 117-124. [CrossRef]

53. Jensen, H. Nonsymbiotic nitrogen fixation. Soil Nitrogen 1965, 10, 436-480. [CrossRef]

54. Ehmann, A. The van URK-Salkowski reagent-A sensitive and specific chromogenic reagent for silica gel thin-layer chromatographic detection and identification of indole derivatives. J. Chromatogr. A 1977, 132, 267-276. [CrossRef]

55. Leveau, J.H.; Lindow, S.E. Utilization of the plant hormone indole-3-acetic acid for growth by Pseudomonas putida strain 1290. Appl. Environ. Microbiol. 2005, 71, 2365-2371. [CrossRef] [PubMed]

56. Gandhi, A.; Muralidharan, G. Assessment of zinc solubilizing potentiality of Acinetobacter sp. isolated from rice rhizosphere. Eur. J. Soil Biol. 2016, 76, 1-8. [CrossRef]

57. Khanghahi, M.Y.; Ricciuti, P.; Allegretta, I.; Terzano, R.; Crecchio, C. Solubilization of insoluble zinc compounds by zinc solubilizing bacteria (ZSB) and optimization of their growth conditions. Environ. Sci. Pollut. Res. 2018, 25, 25862-25868. [CrossRef] [PubMed]

58. Schwyn, B.; Neilands, J.B. Universal chemical assay for the detection and determination of siderophores. Anal. Biochem. 1987, 160, 47-56. [CrossRef]

59. Cappuccino, J.G.; Sherman, N. Microbiology: A Laboratory ManualA Laboratory Manual, 3rd ed.; Benjamin/Cumming Pub. Co.: New York, NY, USA, 1992.

60. Chrouqi, L.; Lahcen, O.; Jadrane, I.; Koussa, T.; Alfeddy, M.N. Screening of soil rhizobacteria isolated from wheat plants grown in the Marrakech region (Morocco, North Africa) for plant growth promoting activities. JMES 2017, 8, 3382-3390.

61. Kasana, R.C.; Salwan, R.; Dhar, H.; Dutt, S.; Gulati, A. A rapid and easy method for the detection of microbial cellulases on agar plates using gram's iodine. Curr. Microbiol. 2008, 57, 503-507. [CrossRef]

62. Kavitha, T.; Nelson, R.; Jesi, S.J. Screening of rhizobacteria for plant growth promoting traits and antifungal activity against charcoal rot pathogen Macrophomina phaseolina. Int. J. Pharma Bio Sci. 2013, 4, B-177-B-186.

63. Smibert, R. Phenotypic characterization. Methods Gen. Mol. Bacteriol. 1994, 16, 3-11.

64. Armalytè, J.; Skerniškytè, J.; Bakienè, E.; Krasauskas, R.; Šiugždinienè, R.; Kareivienè, V.; Kerzienè, S.; Klimienè, I.; Sužiedėlienè, E.; Ružauskas, M. Microbial Diversity and Antimicrobial Resistance Profile in Microbiota From Soils of Conventional and Organic Farming Systems. Front. Microbiol. 2019, 10, 892. [CrossRef]

65. Syal, K.; Mo, M.; Yu, H.; Iriya, R.; Jing, W.; Guodong, S.; Wang, S.; Grys, T.E.; Haydel, S.E.; Tao, N. Current and emerging techniques for antibiotic susceptibility tests. Theranostics 2017, 7, 1795-1805. [CrossRef]

66. Taylor, R.G.; Walker, D.C.; McInnes, R.R. E. coli host strains significantly affect the quality of small scale plasmid DNA preparations used for sequencing. Nucleic Acids Res. 1993, 21, 1677-1678. [CrossRef]

67. Bauer, A. Antibiotic susceptibility testing by a standardized single disc method. Am. J. Clin. Pathol. 1966, 45, 149-158. [CrossRef]

68. Ryan, K.J.; Schoenknecht, F.D.; Kirby, W.M. Disc sensitivity testing. Hosp. Pract. 1970, 5, 91-100. [CrossRef]

69. Fuchs, P.C.; Barry, A.L.; Brown, S.D. Selection of zone size interpretive criteria for disk diffusion susceptibility tests of three antibiotics against Streptococcus pneumoniae, using the New Guidelines of the National Committee for Clinical Laboratory Standards. Antimicrob. Agents Chemother. 2002, 46, 398-401. [CrossRef]

70. Cervantes-Vega, C.; Chavez, J.; Córdova, N.; Amador, J.V. Resistance to metals by Pseudomonas aeruginosa clinical isolates. Microbios 1986, 48, 159-163.

71. Khan, N.; Zandi, P.; Ali, S.; Mehmood, A.; Adnan Shahid, M.; Yang, J. Impact of salicylic acid and PGPR on the drought tolerance and phytoremediation potential of Helianthus annus. Front. Microbiol. 2018, 9, 2507. [CrossRef] [PubMed]

72. Sarkar, A.; Ghosh, P.K.; Pramanik, K.; Mitra, S.; Soren, T.; Pandey, S.; Mondal, M.H.; Maiti, T.K. A halotolerant Enterobacter sp. displaying ACC deaminase activity promotes rice seedling growth under salt stress. Res. Microbiol. 2018, 169, 20-32. [CrossRef] [PubMed]

73. Ji, S.H.; Gururani, M.A.; Chun, S.C. Isolation and characterization of plant growth promoting endophytic diazotrophic bacteria from Korean rice cultivars. Microbiol. Res. 2014, 169, 83-98. [CrossRef] [PubMed]

74. Bybordi, A. The influence of salt stress on seed germination, growth and yield of canola cultivars. Not. Bot. Horti Agrobot. Cluj-Napoca 2010, 38, 128-133. [CrossRef]

75. Islam, S.; Mannan Akanda, A.; Prova, A.; Islam, T.; Hossain, M. Isolation and Identification of Plant Growth Promoting Rhizobacteria from Cucumber Rhizosphere and Their Effect on Plant Growth Promotion and Disease Suppression. Front. Microbiol. 2016, 6, 1360. [CrossRef] 
76. Usha, S.; Padmavathi, T. Phosphate solubilizers from the rhizosphere of Piper nigrum L. in Karnataka, India. Chil. J. Agric. Res. 2012, 72, 397-403. [CrossRef]

77. Welbaum, G.E.; Sturz, A.V.; Dong, Z.; Nowak, J. Managing soil microorganisms to improve productivity of agro-ecosystems. Crit. Rev. Plant Sci. 2004, 23, 175-193. [CrossRef]

78. Kshetri, L.; Naseem, F.; Pandey, P. Role of Serratia sp. as Biocontrol Agent and Plant Growth Stimulator, with Prospects of Biotic Stress Management in Plant. In Plant Growth Promoting Rhizobacteria for Sustainable Stress Management; Springer: Berlin/Heidelberg, Germany, 2019; pp. 169-200. [CrossRef]

79. Alraey, D.A.; Haroun, S.A.; Omar, M.N.; Abd-ElGawad, A.M.; El-Shobaky, A.M.; Mowafy, A.M. Fluctuation of essential oil constituents in Origanum syriacum subsp. sinaicum in response to plant growth promoting bacteria. J. Essent. Oil Bear. Plants 2019, 22, 1022-1033. [CrossRef]

80. Sabu, R.; Aswani, R.; Jishma, P.; Jasim, B.; Mathew, J.; Radhakrishnan, E.K. Plant Growth Promoting Endophytic Serratia sp. ZoB14 Protecting Ginger from Fungal Pathogens. Proc. Natl. Acad. Sci. India Sect. B Biol. Sci. 2019, 89, 213-220. [CrossRef]

81. Lee, S.; Flores-Encarnacion, M.; Contreras-Zentella, M.; Garcia-Flores, L.; Escamilla, J.; Kennedy, C. Indole-3-acetic acid biosynthesis is deficient in Gluconacetobacter diazotrophicus strains with mutations in cytochrome c biogenesis genes. J. Bacteriol. 2004, 186, 5384-5391. [CrossRef]

82. Zelaya-Molina, L.X.; Hernández-Soto, L.M.; Guerra-Camacho, J.E.; Monterrubio-López, R.; Patiño-Siciliano, A.; Villa-Tanaca, L.; Hernández-Rodríguez, C. Ammonia-Oligotrophic and Diazotrophic Heavy Metal-Resistant Serratia liquefaciens Strains from Pioneer Plants and Mine Tailings. Microb. Ecol. 2016, 72, 324-346. [CrossRef]

83. Yang, R.; Li, J.; Wei-Xie, L.; Shao, L. Oligotrophic Nitrification and Denitrification Bacterial Communities in a Constructed Sewage Treatment Ecosystem and Nitrogen Removal of Delftia tsuruhatensis NF4. Pol. J. Microbiol. 2020, 69, 99-108. [CrossRef]

84. Gorzala, G.; Jablonska-Gorzala, D.; Chojnicki, J.; Gozdowski, D.; Russel, S. Influence of soil pH modification on the number of oligonitrophilic yeast. Rocz. Glebozn. 2003, 54, 35-42.

85. Jamil, A.; Riaz, S.; Ashraf, M.; Foolad, M.R. Gene expression profiling of plants under salt stress. Crit. Rev. Plant Sci. 2011, 30, 435-458. [CrossRef]

86. Zhang, H.; Sun, Y.; Xie, X.; Kim, M.S.; Dowd, S.E.; Paré, P.W. A soil bacterium regulates plant acquisition of iron via deficiencyinducible mechanisms. Plant J. 2009, 58, 568-577. [CrossRef] [PubMed]

87. Barriuso, J.; Solano, B.R.; Gutiérrez Mañero, F. Protection against pathogen and salt stress by four plant growth-promoting rhizobacteria isolated from Pinus sp. on Arabidopsis thaliana. Phytopathology 2008, 98, 666-672. [CrossRef]

88. Mayak, S.; Tirosh, T.; Glick, B.R. Plant growth-promoting bacteria confer resistance in tomato plants to salt stress. Plant Physiol. Biochem. 2004, 42, 565-572. [CrossRef] [PubMed]

89. Rashid, M.; Khalil, S.; Ayub, N.; Alam, S.; Latif, F. Organic acids production and phosphate solubilization by phosphate solubilizing microorganisms (PSM) under in vitro conditions. Pak. J. Biol. Sci. 2004, 7, 187-196. [CrossRef]

90. Mendes, R.; Garbeva, P.; Raaijmakers, J.M. The rhizosphere microbiome: Significance of plant beneficial, plant pathogenic, and human pathogenic microorganisms. FEMS Microbiol. Rev. 2013, 37, 634-663. [CrossRef] [PubMed]

91. Srinivasan, R.; Yandigeri, M.S.; Kashyap, S.; Alagawadi, A.R. Effect of salt on survival and P-solubilization potential of phosphate solubilizing microorganisms from salt affected soils. Saudi J. Biol. Sci. 2012, 19, 427-434. [CrossRef] [PubMed]

92. Demiİr, Y.; Kocaçalişkan, İ. Effects of $\mathrm{NaCl}$ and Proline on Polyphenol Oxidase Activity in Bean Seedlings. Biol. Plant. 2001, 44, 607-609. [CrossRef]

93. Qin, S.; Zhang, Y.-J.; Yuan, B.; Xu, P.-Y.; Xing, K.; Wang, J.; Jiang, J.-H. Isolation of ACC deaminase-producing habitat-adapted symbiotic bacteria associated with halophyte Limonium sinense (Girard) Kuntze and evaluating their plant growth-promoting activity under salt stress. Plant Soil 2014, 374, 753-766. [CrossRef]

94. Gujral, M.S.; Agrawal, P.; Khetmalas, M.B.; Pandey, R. Colonization and plant growth promotion of Sorghum seedlings by endorhizospheric Serratia sp. Acta Biol. Indica 2013, 2, 343-352.

95. Patten, C.L.; Glick, B.R. Role of Pseudomonas putida indoleacetic acid in development of the host plant root system. Appl. Environ. Microbiol. 2002, 68, 3795-3801. [CrossRef]

96. Sharafzadeh, S. Effects of PGPR on growth and nutrients uptake of tomato. Int. J. Adv. Eng. Technol. $2012,2,27$.

97. Gyaneshwar, P.; Parekh, L.; Archana, G.; Poole, P.; Collins, M.; Hutson, R.; Kumar, G.N. Involvement of a phosphate starvation inducible glucose dehydrogenase in soil phosphate solubilization by Enterobacter asburiae. FEMS Microbiol. Lett. 1999, 171, 223-229. [CrossRef]

98. Spaepen, S.; Vanderleyden, J.; Remans, R. Indole-3-acetic acid in microbial and microorganism-plant signaling. FEMS Microbiol. Rev. 2007, 31, 425-448. [CrossRef] [PubMed]

99. Siddikee, M.A.; Chauhan, P.; Anandham, R.; Han, G.-H.; Sa, T. Isolation, characterization, and use for plant growth promotion under salt stress, of ACC deaminase-producing halotolerant bacteria derived from coastal soil. J. Microbiol. Biotechnol. 2010, 20, 1577-1584. [CrossRef] [PubMed]

100. Jha, B.; Gontia, I.; Hartmann, A. The roots of the halophyte Salicornia brachiata are a source of new halotolerant diazotrophic bacteria with plant growth-promoting potential. Plant Soil 2012, 356, 265-277. [CrossRef]

101. Berg, G.; Alavi, M.; Schmidt, C.S.; Zachow, C.; Egamberdieva, D.; Kamilova, F.; Lugtenberg, B. Biocontrol and osmoprotection for plants under salinated conditions. Mol. Microb. Ecol. Rhizosphere 2013, 1, 561-573.

102. Dodd, I.C.; Pérez-Alfocea, F. Microbial amelioration of crop salinity stress. J. Exp. Bot. 2012, 63, 3415-3428. [CrossRef] [PubMed] 
103. Havenaar, R.; Ten Brink, B.; Huis, J.H. Selection of strains for probiotic use. In Probiotics; Springer: Berlin/Heidelberg, Germany, 1992; pp. 209-224. [CrossRef]

104. Ali, H.; Khan, E.; Sajad, M.A. Phytoremediation of heavy metals-Concepts and applications. Chemosphere 2013, 91, 869-881. [CrossRef]

105. Oves, M.; Khan, M.S.; Qari, H.A. Ensifer adhaerens for heavy metal bioaccumulation, biosorption, and phosphate solubilization under metal stress condition. J. Taiwan Inst. Chem. Eng. 2017, 80, 540-552. [CrossRef]

106. Campos, V.; Moraga, R.; Yánez, J.; Zaror, C.; Mondaca, M. Chromate reduction by Serratia marcescens isolated from tannery effluent. Bull. Environ. Contam. Toxicol. 2005, 75, 400. [CrossRef] [PubMed]

107. Halder, U.; Banerjee, A.; Biswas, R.; Sharma, A.; Pal, S.; Adhikary, A.; Bandopadhyay, R. Production of prodigiosin by a drug-resistant Serratia rubidaea HB01 isolated from sewage. Environ. Sustain. 2020, 3, 279-287. [CrossRef]

108. Jalal, K.; UT, N.F.; Mardiana, M.; Shahbudin, S.; Omar, M.N. Antibiotic resistance microbes in tropical mangrove sediments in east coast peninsular, Malaysia. Afr. J. Microbiol. Res. 2010, 4, 640-645. [CrossRef]

109. Ibrahim, M.K.; Galal, A.-M.M.; Al-Turk, I.M.; Al-Zhrany, K.D. Antibiotic resistance in Gram-negative pathogenic bacteria in hospitals' drain in Al-Madina Al-Munnawara. J. Taibah Univ. Sci. 2010, 3, 14-22. [CrossRef]

110. Gentille, D.; Pérez, M.; Centelles, M.J. [Bacteremia by a Serratia rubidaea with an atypical quinolones resistance phenotype]. Rev. Chil. Infectol 2014, 31, 351-352. [CrossRef] [PubMed]

111. Ursua, P.R.; Unzaga, M.J.; Melero, P.; Iturburu, I.; Ezpeleta, C.; Cisterna, R. Serratia rubidaea as an invasive pathogen. J. Clin. Microbiol. 1996, 34, 216-217. [CrossRef]

112. Litterio, M.R.; Arazi, S.; Hernández, C.; Lopardo, H. Isolation of Serratia rubidaea from a mixed infection after a horse bite. Rev. Argent. De Microbiol. 2012, 44, 272-274.

113. Xue, Y.; Sun, Q.; Liu, W.; Xiuyun, Y.; Guangqian, P.; Wang, Y.; An, X.; Zhiqiang, M.; Yaping, L.; Yigang, T. Complete genome sequence of Serratia rubidaea isolated in China. Genome Announc. 2016, 4. [CrossRef]

114. Yasmin, F.; Othman, R.; Sijam, K.; Saad, M.S. Characterization of beneficial properties of plant growth-promoting rhizobacteria isolated from sweet potato rhizosphere. Afr. J. Microbiol. Res. 2009, 3, 815-821. [CrossRef]

115. Lim, Y.-L.; Yong, D.; Ee, R.; Krishnan, T.; Tee, K.-K.; Yin, W.-F.; Chan, K.-G. Complete genome sequence of Serratia fonticola DSM 4576T, a potential plant growth promoting bacterium. J. Biotechnol. 2015, 214, 43-44. [CrossRef]

116. Aylward, F.O.; Tremmel, D.M.; Starrett, G.J.; Bruce, D.C.; Chain, P.; Chen, A.; Davenport, K.W.; Detter, C.; Han, C.S.; Han, J. Complete genome of Serratia sp. strain FGI 94, a strain associated with leaf-cutter ant fungus gardens. Genome Announc. 2013, 1. [CrossRef]

117. Kluepfel, D.A. The behavior and tracking of bacteria in the rhizosphere. Annu. Rev. Phytopathol. 1993, 31, 441-472. [CrossRef]

118. Trivedi, P.; Pandey, A.; Palni, L.M.S.; Bag, N.; Tamang, M. Colonization of Rhizosphere of Tea by Growth Promoting Bacteria. 2004. Available online: http:/ / hdl.handle.net/2263/8370 (accessed on 8 March 2021).

119. Ramakrishna, W.; Yadav, R.; Li, K. Plant growth promoting bacteria in agriculture: Two sides of a coin. Appl. Soil Ecol. 2019, 138, 10-18. [CrossRef]

120. Kumar, A.; Munder, A.; Aravind, R.; Eapen, S.; Tümmler, B.; Raaijmakers, J. Friend or foe: Genetic and functional characterization of plant endophytic P seudomonas aeruginosa. Environ. Microbiol. 2013, 15, 764-779. [CrossRef]

121. Wu, L.; Wang, H.; Zhang, Z.; Lin, R.; Zhang, Z.; Lin, W. Comparative metaproteomic analysis on consecutively Rehmannia glutinosa-monocultured rhizosphere soil. PLoS ONE 2011, 6, e20611. [CrossRef]

122. Farmer, J.; Davis, B.R.; Hickman-Brenner, F.; McWhorter, A.; Huntley-Carter, G.; Asbury, M.; Riddle, C.; Wathen-Grady, H.; Elias, C.; Fanning, G. Biochemical identification of new species and biogroups of Enterobacteriaceae isolated from clinical specimens. J. Clin. Microbiol. 1985, 21, 46-76. [CrossRef]

123. Nalini, S.; Parthasarathi, R. Optimization of rhamnolipid biosurfactant production from Serratia rubidaea SNAU02 under solid-state fermentation and its biocontrol efficacy against Fusarium wilt of eggplant. Ann. Agrar. Sci. 2018, 16, 108-115. [CrossRef]

124. Kalbe, C.; Marten, P.; Berg, G. Strains of the genus Serratia as beneficial rhizobacteria of oilseed rape with antifungal properties. Microbiol. Res. 1996, 151, 433-439. [CrossRef]

125. Al-Mijalli, S.H.S. Isolation and characterization of plant and human pathogenic bacteria from green pepper (Capsicum annum L.) in Riyadh, Saudi Arabia. 3 Biotech 2014, 4, 337-344. [CrossRef] [PubMed]

126. Pence, N.S.; Larsen, P.B.; Ebbs, S.D.; Letham, D.L.; Lasat, M.M.; Garvin, D.F.; Eide, D.; Kochian, L.V. The molecular physiology of heavy metal transport in the Zn/Cd hyperaccumulator Thlaspi caerulescens. Proc. Natl. Acad. Sci. USA 2000, 97, 4956-4960. [CrossRef] [PubMed] 